Portland State University

PDXScholar

Civil and Environmental Engineering Master's

Project Reports

2017

\title{
Seismic Retrofit Case Study of Reinforced Concrete Bridges with Buckling Restrained Braces
}

Michael K. Miotke

Portland State University

Follow this and additional works at: https://pdxscholar.library.pdx.edu/cengin_gradprojects

Part of the Civil Engineering Commons

Let us know how access to this document benefits you.

\section{Recommended Citation}

Miotke, Michael K., "Seismic Retrofit Case Study of Reinforced Concrete Bridges with Buckling Restrained Braces" (2017). Civil and Environmental Engineering Master's Project Reports. 33.

https://doi.org/10.15760/CEEMP.4

This Project is brought to you for free and open access. It has been accepted for inclusion in Civil and Environmental Engineering Master's Project Reports by an authorized administrator of PDXScholar. Please contact us if we can make this document more accessible: pdxscholar@pdx.edu. 
SEISMIC RETROFIT CASE STUDY OF REINFORCED CONCRETE BRIDGES WITH BUCKLING RESTRAINED BRACES

\author{
BY \\ MICHAEL K. MIOTKE \\ A research project report submitted in partial fulfillment \\ of the requirement for the degree of

\section{MASTER OF SCIENCE} \\ IN \\ CIVIL AND ENVIRONMENTAL ENGINEERING
}

\author{
Project Advisor: \\ Peter Dusicka
}

Portland State University

(C)2017 


\section{ACKNOWLEDGMENTS}

Special thanks to Portland State University for the opportunity to conduct this research project and for the continuous support throughout the process. This paper is a continuation of research funded by the Oregon Department of Transportation whose interest in the pursuit of new ideas and willingness to collaborate is greatly appreciated. Any opinions, findings, and conclusions or recommendations expressed in this material are those of the author and do not necessarily reflect the views of any of the sponsors. 


\begin{abstract}
Many highway bridges in Oregon have been designed with minimal considerations for seismic hazard and are in need of retrofit. Although buckling restrained braces (BRBs) are not necessarily a new concept, using them to seismically retrofit bridges is. This case study investigates the $\mathrm{BRB}$ retrofit concept as compared to traditional retrofit measures for a sample of typical vulnerable bridges in Oregon. The objectives of evaluating these cases were to determine the feasibility of the concept both in terms of performance as well as construction costs. This study builds on the ongoing research at Portland State University into the development of the fuse retrofit concept for Oregon highway bridges and follows recently completed large scale laboratory tests of BRB retrofitted bents.
\end{abstract}

Three reinforced concrete highway bridges were selected from the Oregon Department of Transportation (ODOT) bridge inventory to represent a typical layout that characterizes numerous bridges that are seismically vulnerable across Oregon. The three bridges included varying skews and pier cap beam configurations to determine the impact of these characteristics on the seismic retrofit implementation and performance. Seismic vulnerability assessments of the existing bridges were conducted in accordance with the guidelines of the ODOT Bridge Design and Drafting Manual (BDDM). Preliminary designs were then developed considering conventional retrofit measures as well as the newly proposed retrofit measure utilizing BRBs as ductile fuses. Comparison was then made among the bridges relative to their expected seismic performance and estimated retrofit construction cost. The results of the analyses have shown that bridge retrofits using BRBs can be not only feasible, but also a cost effective retrofit strategy and should be part of the designer's toolbox when considering bridge seismic retrofits. 


\section{TABLE OF CONTENTS}

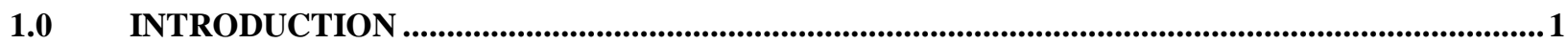

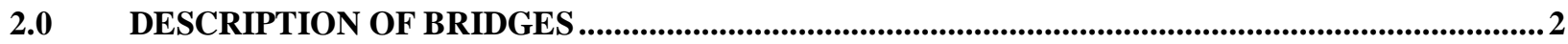

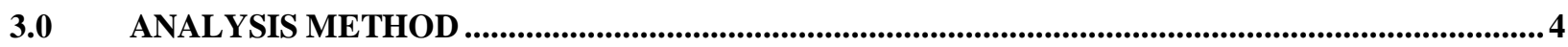

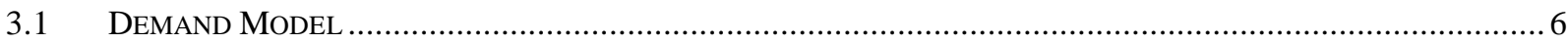

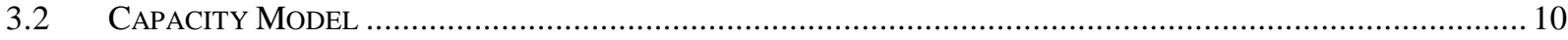

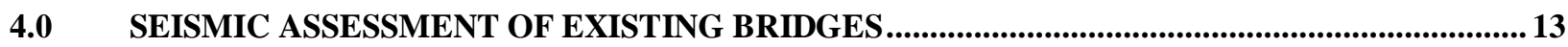

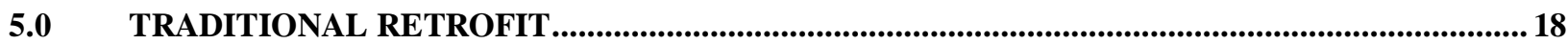

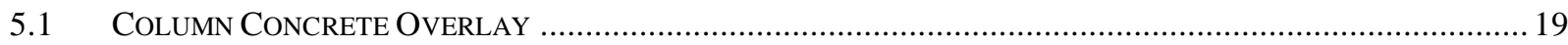

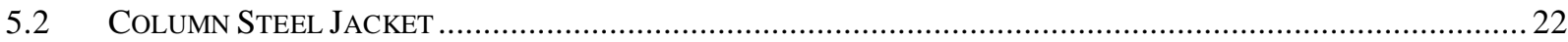

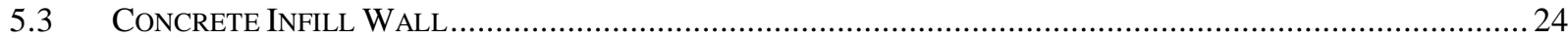

6.0 BUCKLING RESTRAINED BRACE RETROFIT …....................................................................2 27

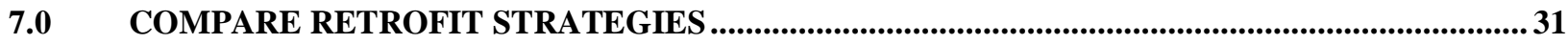

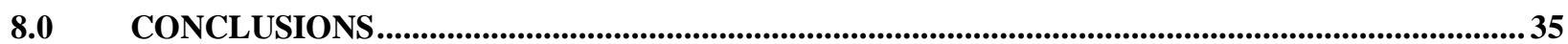

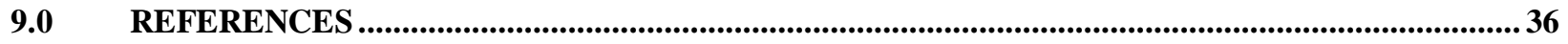




\section{LIST OF TABLES}

Table 1. Summary of selected bridge characteristics 2

Table 2. Fundamental periods of vibration of existing bridges ................................................................

Table 3. Ductility demands and displacement magnification factors for existing bridges ................................. 9

Table 4. Summary of performance criteria for column concrete overlay retrofits........................................20

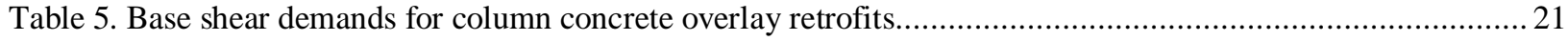

Table 6. Preliminary construction cost estimates for column concrete overlay retrofits.................................22

Table 7. Summary of performance criteria for column steel jacket retrofits ................................................. 23

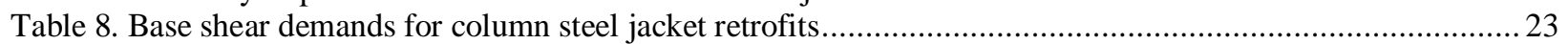

Table 9. Preliminary construction cost estimates for column steel jacket retrofits ......................................24

Table 10. Summary of performance criteria for concrete infill wall retrofits............................................25

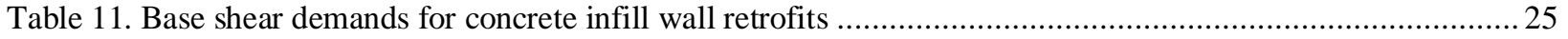

Table 12. Preliminary construction cost estimates for concrete infill wall retrofits......................................26

Table 13. Design properties of BRB retrofits................................................................................... 28

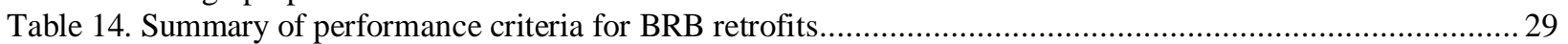

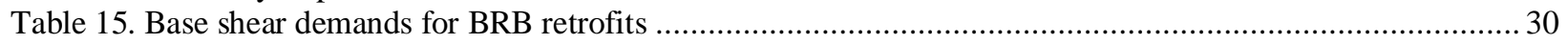

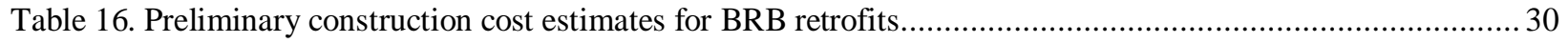




\section{LIST OF FIGURES}

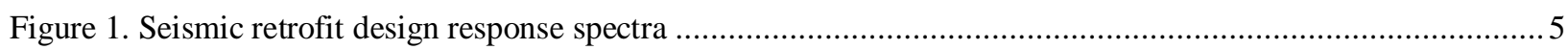

Figure 2. Abutment foundation spring modeling …............................................................................ 7

Figure 3. Comparison of fixed versus flexible foundations for the blue bridge ........................................ 8

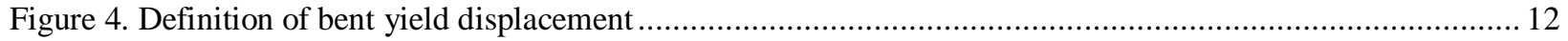

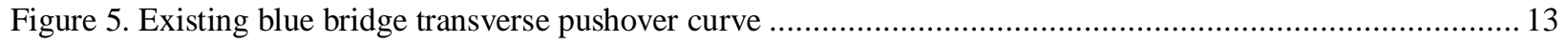

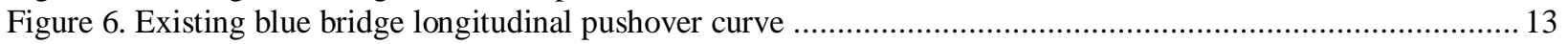

Figure 7. Existing green bridge transverse pushover curve.................................................................. 14

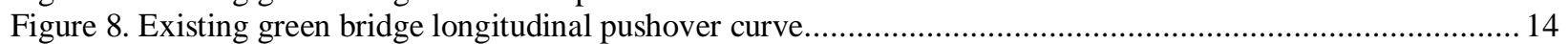

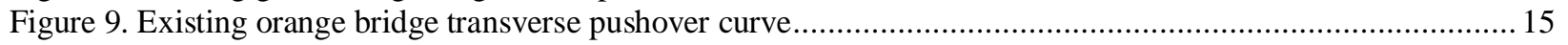

Figure 10. Existing orange bridge longitudinal pushover curve ............................................................. 15

Figure 11. Existing hinge curvature ductility demands at LL ground motion ............................................. 16

Figure 12. Existing hinge curvature ductility demands at UL ground motion............................................... 17

Figure 13. Orange bridge example column concrete overlay retrofit design................................................ 20

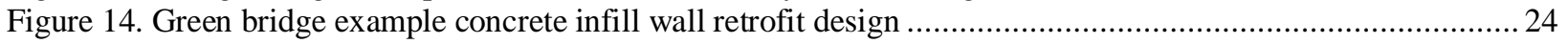

Figure 15. Blue bridge example BRB retrofit design ......................................................................29

Figure 16. Comparison of performance criteria assessment for transverse demands.......................................31

Figure 17. Comparison of performance criteria assessment for longitudinal demands.................................. 32

Figure 18. Percentage of transverse base shear increase from existing bridges ......................................... 33

Figure 19. Percentage of longitudinal base shear increase from existing bridges ........................................ 33

Figure 20. Comparison of total preliminary construction cost estimates for all retrofits ................................. 34 


\subsection{INTRODUCTION}

The majority of applications using BRBs for seismic design in today's infrastructure are related to buildings. There have not been many, if any, examples of BRBs used as an earthquake resisting element (ERE) as part of a bridge's earthquake resisting system (ERS). There has been an increasing amount of interest and study of the concept of using BRBs to seismically retrofit existing bridges. A fair amount of research can be found related to the design and theoretical implementation of BRBs for seismically retrofitting reinforced concrete bridge bents.

The BRB concept has been analytically proven to be a feasible and effective strategy for dissipating energy and reducing seismic demands on existing reinforced concrete frames. This case study attempts to build upon that existing research and considers the performance of the BRB retrofit relative to other, more commonly used retrofit strategies in terms of both seismic response and cost effectiveness. Having an analytically sound approach to seismically retrofitting aging infrastructure is not ideal if it is cost prohibitive to implement.

The results of this case study, however, indicate that the BRB retrofit strategy is not only analytically beneficial, but also financially attractive relative to other means currently in use. 


\subsection{DESCRIPTION OF BRIDGES}

A list was generated of Oregon bridges with at least two spans, built between 1950 and 1970, and with intermediate piers comprised of multiple reinforced concrete columns. These are the types of structures commonly requiring seismic retrofitting that are believed will benefit the most from the BRB approach. Bridges built during this time period often exhibit some or all of the following detailing practices, which were prevalent at the time:

- $\quad$ Lap-spliced column reinforcement in plastic hinge regions

- Minimal column transverse reinforcement providing little confinement and shear strength

- $\quad$ Early termination and poor anchorage of pier cap beam flexural reinforcement

- $\quad$ Footings without a top mat of reinforcing

- Insufficient pile embedment to develop tie down forces (uplift in piles)

These details were demonstrated by Priestley, Seible, and Calvi to perform poorly during seismic events in the Seismic Design and Retrofit of Bridges (1996).

From this list of bridges, three were selected based on their location, the skew angle of their supports, and the crossbeam configuration. The magnitude of the seismic hazard is dependent upon the location of the bridge. All three bridges were selected from locations with large seismic design hazards, increasing the likelihood retrofitting would be required. One bridge was selected with supports skewed greater than 30 degrees and one with an integral pier cap. The variability between the selected bridges helped identify the impacts these characteristics have on retrofit implementation and performance. Additionally, it allows the results of this project to be applicable to a wider array of structures.

Each bridge was assigned a unique color to facilitate differentiating between them in figures and tables. The bridges will be identified by their assigned color throughout this report. The color and characteristics of each bridge are provided in Table 1.

Table 1. Summary of selected bridge characteristics

\begin{tabular}{|c|c|c|c|c|c|}
\hline Bridge & Year Built & Spans & Skew & Superstructure & Pier Cap \\
\hline Blue & 1966 & 3 & $0^{\circ}$ & PS Girders & Drop \\
\hline Green & 1967 & 3 & $37^{\circ}$ & PS Girders & Drop \\
\hline Orange & 1954 & 3 & $0^{\circ}$ & CIP Deck Girders & Integral \\
\hline
\end{tabular}


All three bridges consisted of three spans and have two intermediate supports, or bents. In all three bridges, there is very little difference between Bents 2 and 3. The blue and orange bridges are very symmetrical, and the demands on the Bents are very similar as well. However, the green bridge does have more variability between spans, and Bent 2 exhibited greater demands than Bent 3. Therefore, Bent 2 was chosen for the assessment and retrofit design for all three bridges. Capacity analyses and retrofit designs were not performed for Bent 3 in any of the bridges. However, the retrofits designed for Bent 2 were also applied to Bent 3 for modeling elastic demands of the retrofitted structures. 


\subsection{ANALYSIS METHOD}

This case study attempted to simulate the seismic retrofit procedure for a typical Oregon bridge. Therefore, the seismic analyses were conducted in accordance with the Oregon Department of Transportation Bridge Design and Drafting Manual (ODOT BDDM; 2016). ODOT uses displacement-based seismic design philosophy in alignment with the Guide Specifications for LRFD Seismic Bridge Design $2^{\text {nd }}$ Edition (American Association of State Highway and Transportation Officials [AASHTO], 2011).

The BDDM recommends the Seismic Retrofitting Manual for Highway Structures (Federal Highway Administration [FHWA], 2006) as a supplemental reference for seismic retrofit design. The FHWA manual, as modified by the BDDM, was the reference used for determining seismic hazards, selecting the evaluation methods, and designing traditional retrofit measures.

To determine the seismic hazards for retrofit design, ODOT and FHWA utilize a two-level performance criteria. All of the bridges selected for this case study are considered of "standard" importance and have an anticipated remaining service life of 16-50 years. Therefore, the minimum performance criteria were life-safety and operational.

Life-safety performance criteria uses an upper level (UL) ground motion based on 7\% probability of exceedance in 75 years (1,000-year return period) and requires that bridges do not collapse. Operational performance criteria uses a lower level (LL) ground motion based on 14\% probability of exceedance in 75 years (500-year return period) and requires that bridges remain essentially elastic. These seismic hazard criteria were in-place at the start of this case study and were used to determine the displacement demands used in this report. The lower and UL response spectra determined for each bridge location are provided in Figure 1.

In October of 2016, after the analyses for this case study were conducted, ODOT adopted a new LL ground motion for seismic retrofit operational performance criteria based on the full-rupture Cascadia Subduction Zone Earthquake (CSZE). The CSZE response spectra for each of the three bridge sites have been included in Figure 1 for information and comparison. 


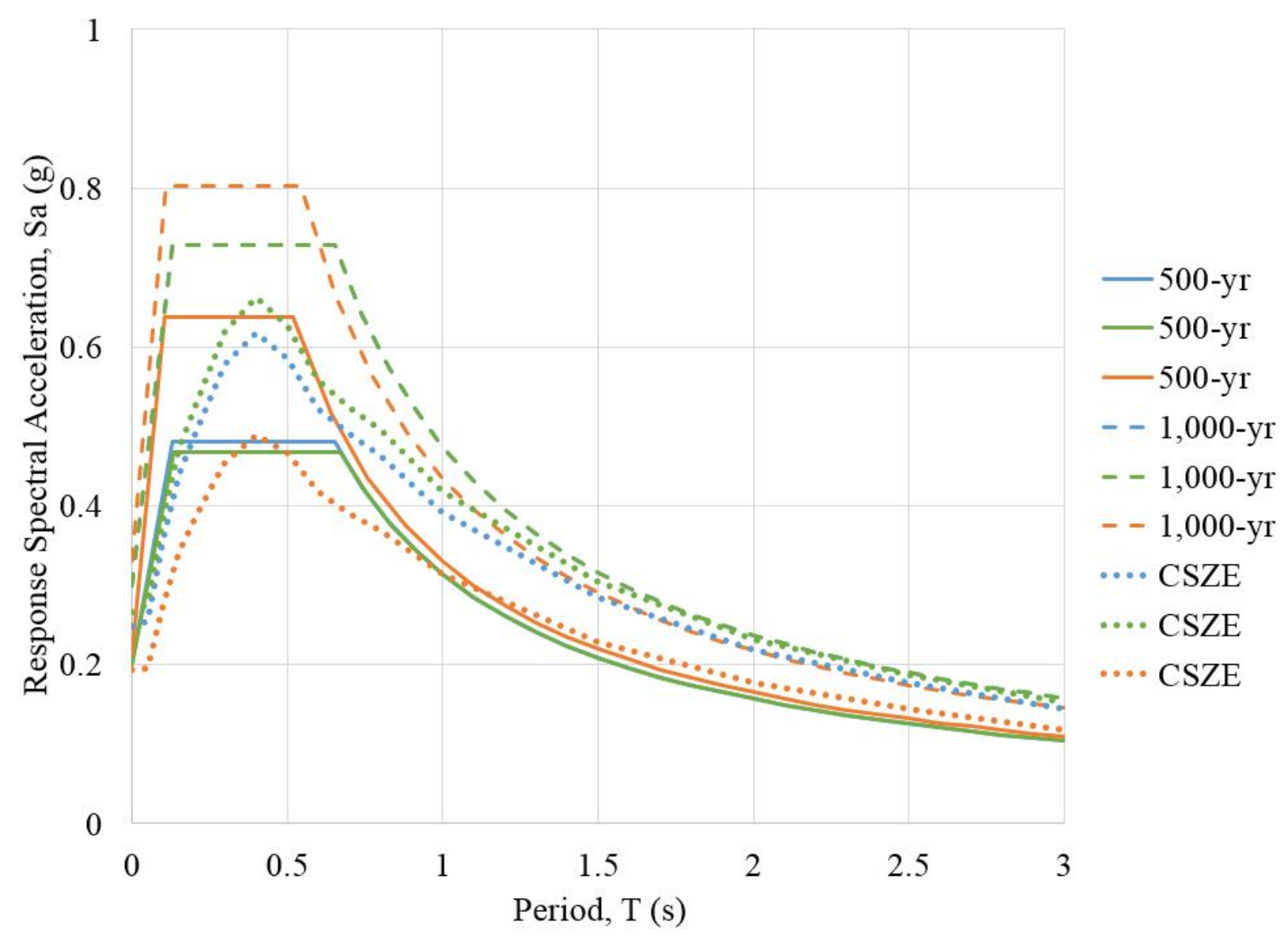

Figure 1. Seismic retrofit design response spectra

The UL ground motions (1,000-yr) for the blue and green bridges have identical spectral accelerations, resulting in overlapping curves. All response spectra curves were developed using Site Class D since limited knowledge of the soils at the bridge sites was available (ODOT, 2016, p. 1-246).

The CSZE curves for the blue and green bridges have generally higher spectral accelerations than the 500-year event used in the analysis. This indicates that retrofits required to meet operational performance criteria would still be required utilizing the CSZE hazard. Peak CSZE spectral accelerations for the orange bridge are less than the 500-year event used in the analysis. For structural vibrations with periods at or above 1.0 seconds, however, spectral accelerations are approximately the same. 


\subsection{Demand Model}

As recommended by the Seismic Retrofitting Manual (FHWA, 2006) the displacement demands for all three bridges were determined from elastic dynamic multimodal analysis. SAP2000 was used to perform the demand analyses. The horizontal ground accelerations were defined relative to the centerline of bridge axes. The longitudinal spectral accelerations occur along the axis parallel to the centerline of the bridge, while the transverse are perpendicular.

Bent displacements are measured at the tops of columns and are relative to the centerline of bent, not the centerline of bridge. This is an important distinction, particularly for the green bridge where the supports are skewed relative to the bridge centerline. "Transverse" bent displacement demands are parallel to the centerline of the bent, and "longitudinal" bent displacement demands are normal to the centerline of the bent.

The superstructure elements were defined as linear elastic frame elements using expected material properties. The software automatically determined and distributed inertial masses based on defined gravity loads and element self-weights.

The abutment contribution to seismic resistance was included in the direction normal to the centerline of bearing only. The end diaphragms engage passive earth pressure in this direction, which is modeled using linear springs. All of the abutments were assumed to fuse in the direction parallel to the centerline of bearing and were modeled as free to translate. Therefore, the girder ends at the abutments were modeled with translational fixity in the vertical axis, linear springs normal to the centerline of bearing, and translational freedom along the centerline of bearing. Rotational freedom was provided about all axes, relying on the connectivity between the girder elements, the composite deck, and the end diaphragms to resist rotations.

In orthogonal bridges, like the blue and orange bridges, passive earth pressure is only engaged at one abutment at a time. The linear springs in the analysis model, however, provide translational resistance in both compression and tension. For these bridges, this behavior was approximated by applying half of the spring stiffness to each end of the bridge. When the bridge deflects longitudinally, both sets of springs are engaged simultaneously and simulate the total resistance provided by one abutment. 
Bridges with skewed supports, like the green bridge, should not be modeled in the same way. During horizontal acceleration, the skew of the supports induces rotations in the bridge about a vertical axis. Due to this rotation, the displacements at one abutment will not be the same as at the other. To model the behavior of skewed bridges, the full abutment spring stiffness is applied to one abutment only. This results in the need for two models, one for each abutment engaging passive earth pressure. The results from both models are then enveloped to determine the maximum reactions for each element under consideration. Figure 2 illustrates the approach used to modeling the abutment springs for orthogonal and skewed bridges.
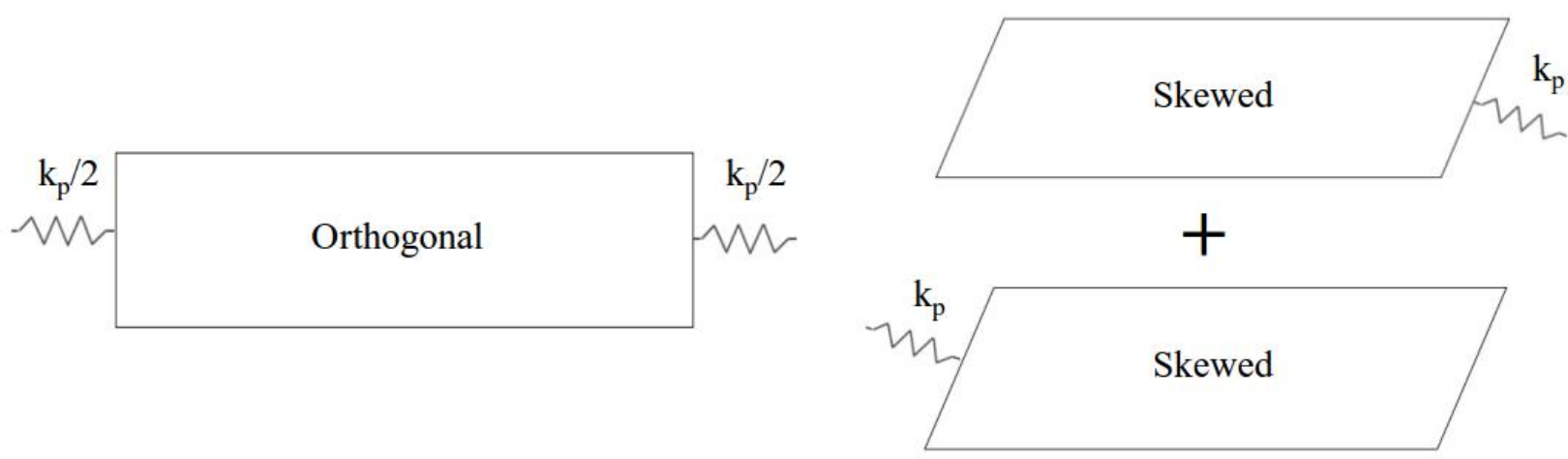

Figure 2. Abutment foundation spring modeling

The cap beams were modeled as continuous frame elements for the full length of the pier. Rigid links connect to the tops of columns, which were modeled as frame elements with expected materials and effective stiffness properties. All frame element sections for the bents were defined using SAP2000's Section Designer, enabling access to Caltrans idealized moment-curvature analysis and auto-hinge definitions. Elastic frame elements representing footings connect the bottom of column to the centroid of the footing. The nodes at the centroid of the footings were used to define foundation modeling behavior.

Fixed foundations were assumed initially based on guidance in the BDDM (ODOT, 2016) and the Guide Specification (AASHTO, 2011). Flexible foundations were also investigated in the existing bridge configurations. The goal of this exercise was to ascertain whether retrofitting could be avoided by considering foundation flexibility.

Uncoupled translation and rotational foundation springs were estimated using the guidance in the BDDM (ODOT, 2016). The demand and capacity analyses of the three existing bridges were 
performed using both fixed foundations and flexible foundations. The flexibility of the foundations did impact the displacement demands and capacities of the piers; however, all three bridges required retrofitting using both assumptions. For example, the transverse pushover results and displacement demands for the blue bridge using both fixed and flexible foundations are provided in Figure 3.

As shown from the transverse force-displacement curve, the total displacements increased using the flexible foundations, but the base shear demands remained the same. The LL displacement demand $\left(\Delta D_{L L}\right)$ exceeded the yield displacement $(\Delta y)$ of the bent, failing to meet the operational performance criteria in both scenarios.

Foundation flexibility and capacity often vary significantly from one structure to another and requires additional investigation and complexity to model accurately. Fixed foundations at the piers were used for this case study in order to make use of consistent boundary conditions and simplify the analysis.

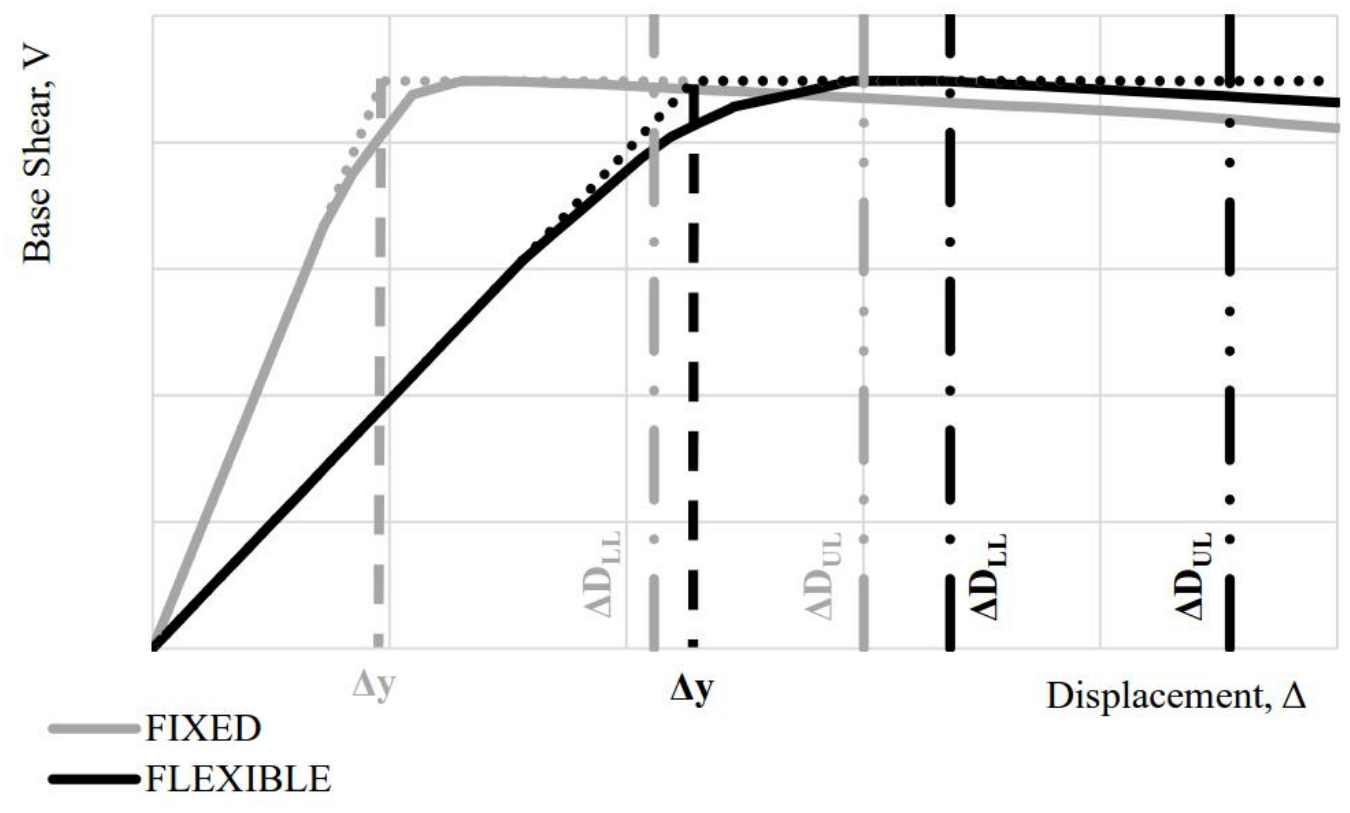

Figure 3. Comparison of fixed versus flexible foundations for the blue bridge

The minimum number of modes generated by each multimodal analysis were increased until $90 \%$ cumulative mass participation was achieved in both directions. The fundamental periods of 
vibration for the longitudinal and transverse axes of the bridges are provided in Table 2. Vertical ground accelerations were not considered.

Table 2. Fundamental periods of vibration of existing bridges

\begin{tabular}{|c|c|c|c|c|c|c|c|c|}
\hline \multirow{2}{*}{$\begin{array}{c}\text { Acceleration } \\
\text { Direction }\end{array}$} & \multicolumn{9}{|c|}{ Bridge } \\
\cline { 2 - 9 } & \multicolumn{2}{|c|}{ Blue } & \multicolumn{2}{c|}{ Green-1* } & \multicolumn{2}{c|}{ Green-4** } & \multicolumn{2}{c|}{ Orange } \\
\cline { 2 - 9 } & Mode & T (s) & Mode & T (s) & Mode & T (s) & Mode & T (s) \\
\hline Transverse & 2 & 0.605 & 2 & 0.486 & 1 & 1.044 & 1 & 1.002 \\
\hline Longitudinal & 3 & 0.435 & 1 & 0.878 & 2 & 0.490 & 3 & 0.316 \\
\hline
\end{tabular}

* Linear springs at abutment 1

** Linear springs at abutment 4

The displacement demands due to the horizontal accelerations along each of the two orthogonal bridge axes were determined from the model. Using the fundamental periods with an assumed initial ductility demand of 6, magnification factors for short-period structures were used to estimate inelastic displacements from the elastic analysis (AASHTO, 2011). The magnified displacements were then combined according to Section 4.4 of the Guide Specification (AASHTO, 2011).

The maximum displacement demands along each axis of the bents were determined from the two load combinations. Once the displacement capacities were determined from the pushover analyses, as discussed in the next section, the maximum displacement ductility demands were calculated for each bridge, and the magnification factors were adjusted accordingly. A few iterations were necessary to determine the final bent ductility demands and magnification factors for each bridge provided in Table 3.

Table 3. Ductility demands and displacement magnification factors for existing bridges

\begin{tabular}{|c|c|c|c|c|c|c|c|c|c|}
\hline \multirow{2}{*}{$\begin{array}{c}\text { Acceleration } \\
\text { Direction }\end{array}$} & \multicolumn{9}{|c|}{ Bridge } \\
\cline { 2 - 9 } \multicolumn{2}{|c|}{ Blue } & \multicolumn{2}{|c|}{ Green-1* } & \multicolumn{2}{c|}{ Green-4** } & \multicolumn{2}{c|}{ Orange } \\
\cline { 2 - 9 }$y$ & $\boldsymbol{\mu D}$ & $\mathbf{R d}$ & $\boldsymbol{\mu D}$ & $\mathbf{R d}$ & $\boldsymbol{\mu D}$ & $\mathbf{R d}$ & $\boldsymbol{\mu D}$ & $\mathbf{R d}$ \\
\hline $500-\mathrm{yr}$ & Transverse & 2.18 & 1.19 & 1.15 & 1.09 & 1.15 & 1.00 & 1.54 & 1.00 \\
\hline $500-\mathrm{yr}$ & Longitudina & 2.18 & 1.47 & 1.15 & 1.00 & 1.15 & 1.09 & 1.54 & 1.37 \\
\hline $1,000-\mathrm{yr}$ & Transverse & 3.47 & 1.25 & 2.19 & 1.37 & 2.19 & 1.00 & 2.03 & 1.00 \\
\hline $1,000-\mathrm{yr}$ & Longitudinal & 3.47 & 1.62 & 2.19 & 1.00 & 2.19 & 1.36 & 2.03 & 1.58 \\
\hline
\end{tabular}

* Linear springs at abutment 1

** Linear springs at abutment 4 
Since the demands from both elastic models for the green bridge were enveloped to determine the bent displacement demands, the maximum ductility demand was applied to both models after each iteration. However, the fundamental periods from each model do vary, so the magnification factors were determined separately for each model and applied to the elastic displacement demands from that model only, prior to being combined and enveloped.

\subsection{Capacity Model}

Displacement capacities of the bents in the transverse and longitudinal directions were determined using nonlinear static analysis, also known as "pushover" analysis. The same SAP2000 analysis models created for the elastic demands were used to perform the pushovers. Nonlinear staged load cases were used, as illustrated in Appendix 4-B.2 of the WSDOT Bridge Design Manual (2015), to isolate individual bents from the global model and perform transverse pushovers on them independently. Longitudinal pushovers of the piers with drop caps were performed in the same way. However, the longitudinal pushover of the orange bridge included the entire structure since the stiffness of the integral superstructure will impact the columns.

The detailing practices discussed in the description of bridges primarily impacts the capacity modeling. Careful consideration was taken to define element capacities and nonlinear behaviors that would accurately model the response of the existing bridge. The modeling of specific elements, such as column regions with lap-spliced reinforcement, used recommendations from the Seismic Design and Retrofit of Bridges (Priestley et al., 1996).

Nonlinear behavior of elements was modeled by defining plastic hinges having idealized bilinear force-displacement curves based on moment-curvature analysis (AASHTO, 2011). Plastic hinges can be defined automatically by SAP2000 using Caltrans P-M auto-hinge definitions. The autohinge definitions were used whenever possible, with the exception of column regions with lapspliced longitudinal reinforcement. These were modeled with user-defined hinges having trilinear moment-curvature behavior as outlined in the Seismic Design and Retrofit of Bridges (Priestley et al., 1996) to account for degradation of tensile capacity of lap-splices under cyclic inelastic displacements.

Hinges were defined for the top and bottom of every column and both ends of each crossbeam span. Additional hinges were provided along the crossbeams at locations where changes in flexural 
reinforcement occurred. This was necessary to capture the impact of premature termination of reinforcement in the crossbeams.

Capacity assessment of the column-to-crossbeam and column-to-footing joints was conducted to ensure plastic hinging occurs in the connecting elements and not in the joints themselves. The joints did not limit the plastic hinging of the connecting elements in any of the bridges in this case study. However, if joint assessment reveals yielding in the joints, preventing formation of hinges in the connecting elements, the plastic hinge definitions in the connecting elements can be modified to account for this behavior (Priestley et al., 1996).

Assessment of the existing footings in all three bridges revealed that they were too weak to develop plastic hinges in the columns and would require retrofitting for stability. Therefore, the footings were modeled as elastic members without plastic hinges defined. This permitted the columns and crossbeams to be assessed by modeling the bents as if footing retrofits had already been provided. Footing retrofits were then designed for each retrofit using capacity protection principles as discussed in the Seismic Retrofitting Manual (FHWA, 2006).

The pushover analyses incrementally displaced the bents until failure. Bent failure is defined as any single plastic hinge reaching its ultimate curvature. Ultimate curvature occurs when either the reinforcement reaches ultimate tensile strain or the concrete reaches ultimate compressive strain, whichever occurs first. The displacement of the bent at, or just prior to, failure was taken as the displacement capacity of the bent, $\Delta \mathrm{C}$.

The other critical displacement determined from the pushover analyses is the yield displacement, $\Delta y$. For bents that form multiple hinges, this is defined as the intersection of the projected initial stiffness and the perfectly plastic portion of the force-displacement curve, as illustrated in Figure 4. 


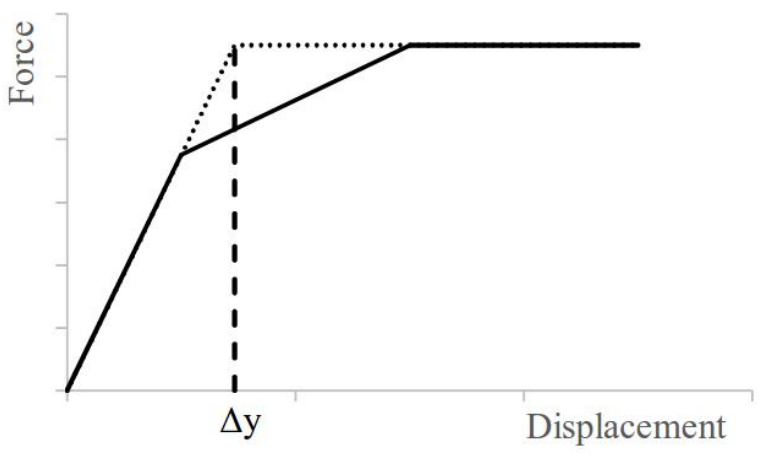

Figure 4. Definition of bent yield displacement

There are exceptions where pushover analyses were not used to determine bent capacities. Reinforced concrete infill walls were considered for traditional retrofit design. These elements were designed to remain essentially elastic under lower and UL seismic demands. Modifying the model to perform pushover analyses on composite pier walls was considered unnecessary since the elastic shear capacities were easily calculated. 


\subsection{SEISMIC ASSESSMENT OF EXISTING BRIDGES}

Force-displacement curves are a common method of displaying pushover analysis results. The yield displacement, displacement capacity, base shear and displacement demands are usually all represented in a single graph. The force-displacement curves for all three bridges in their existing condition (assuming elastic footings) are shown in Figure 5 through Figure 10.

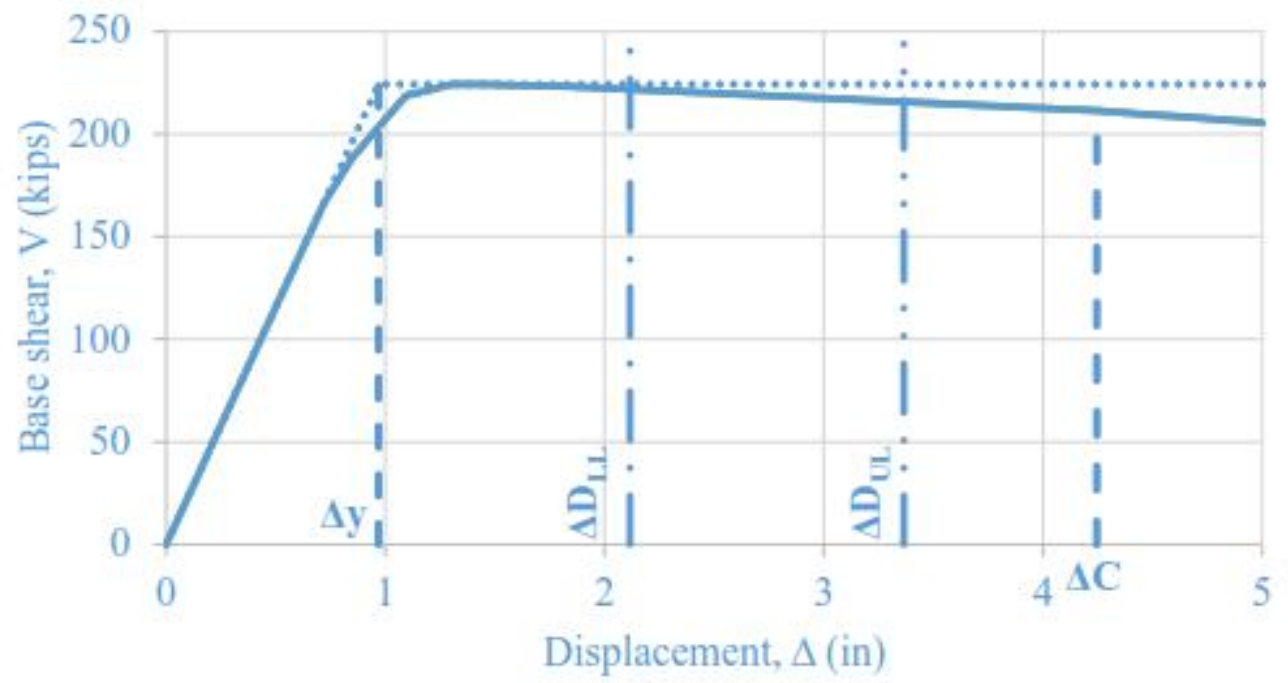

Figure 5. Existing blue bridge transverse pushover curve

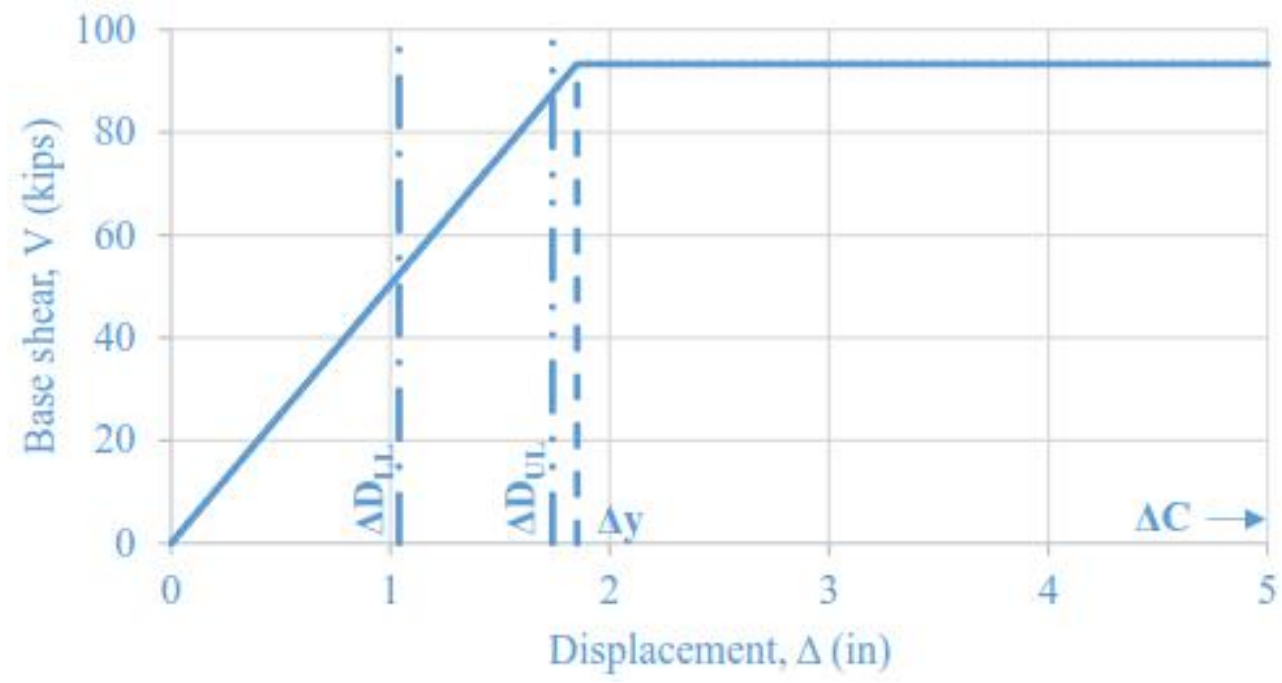

Figure 6. Existing blue bridge longitudinal pushover curve 


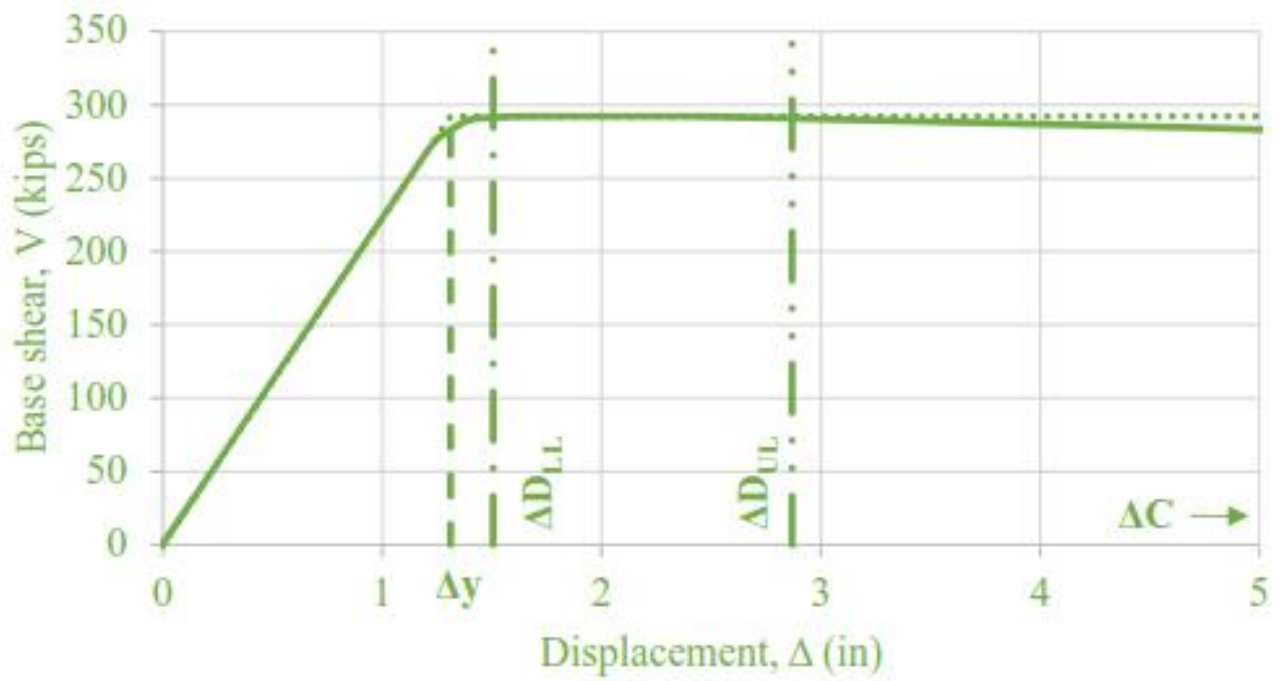

Figure 7. Existing green bridge transverse pushover curve

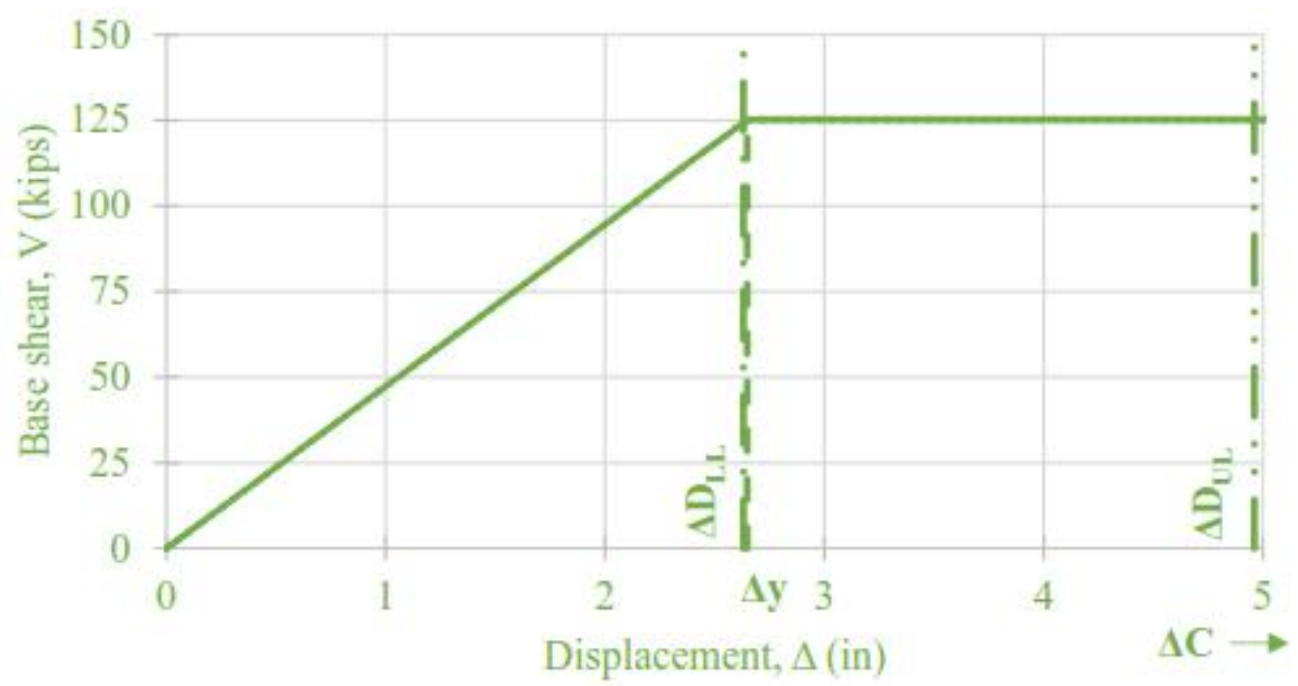

Figure 8. Existing green bridge longitudinal pushover curve 


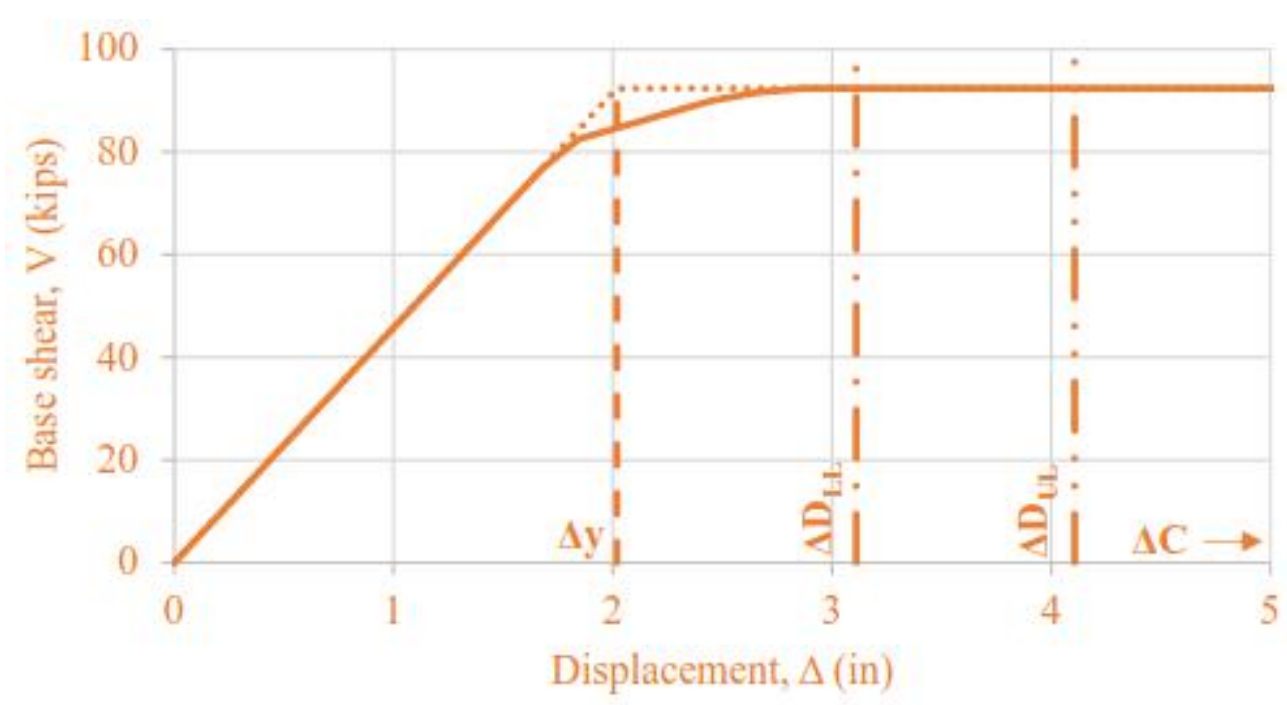

Figure 9. Existing orange bridge transverse pushover curve

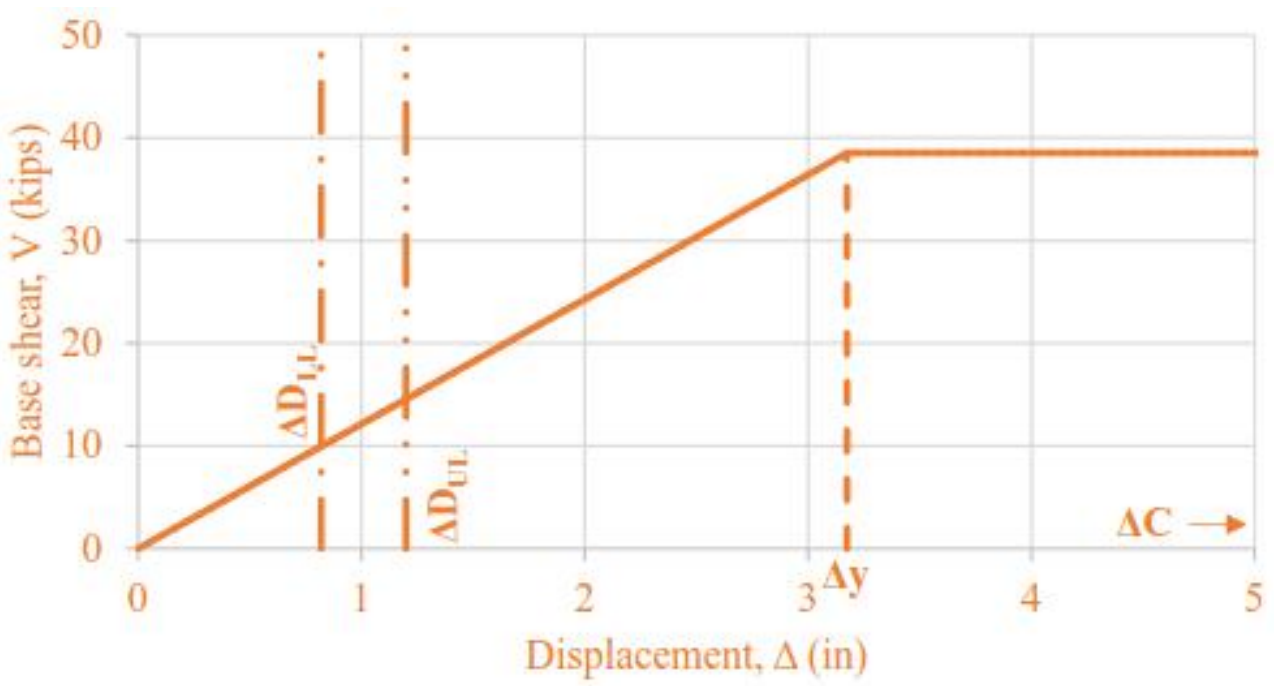

Figure 10. Existing orange bridge longitudinal pushover curve

The skewed supports of the green bridge resulted in much greater out-of-plane (longitudinal) displacement of the bents, to the point where operational performance criteria in the longitudinal direction were barely met. This is the only bridge where the operational performance criteria in the longitudinal direction were even close to failing. This is attributed to the tendency of bridges with skewed supports to rotate during horizontal ground accelerations, resulting in some columns displacing longitudinally more than others.

Life-safety performance criteria is achieved when the bent displacement demand at the UL ground motion, $\Delta \mathrm{D}_{\mathrm{UL}}$, is less than the capacity, $\Delta \mathrm{C}$. The above seismic assessment shows all three bridges 
achieve life-safety performance in both directions and do not require any substructure retrofits to meet this performance criteria.

Operational performance criteria requires the bent displacement demand at the LL ground motion, $\Delta \mathrm{D}_{\mathrm{LL}}$, to be less than the yield displacement, $\Delta \mathrm{y}$. All three bridges satisfy this requirement in the longitudinal direction but not in the transverse direction. Therefore, all three bridges require retrofitting to satisfy the operational performance criteria in the transverse direction.

The yield and displacement capacities of the bent depend on the performance of the individual plastic hinges. The ratio of curvature demand to yield curvature, or curvature ductility $\mu \varphi$, was used to assess the condition of individual hinges at displacement demands. The hinge assessment results are presented in Figure 11 and Figure 12. Curvature ductility values less than 1.0 indicate hinge regions that remained elastic. Values that are greater than 1.0 indicate plastic hinges have formed.

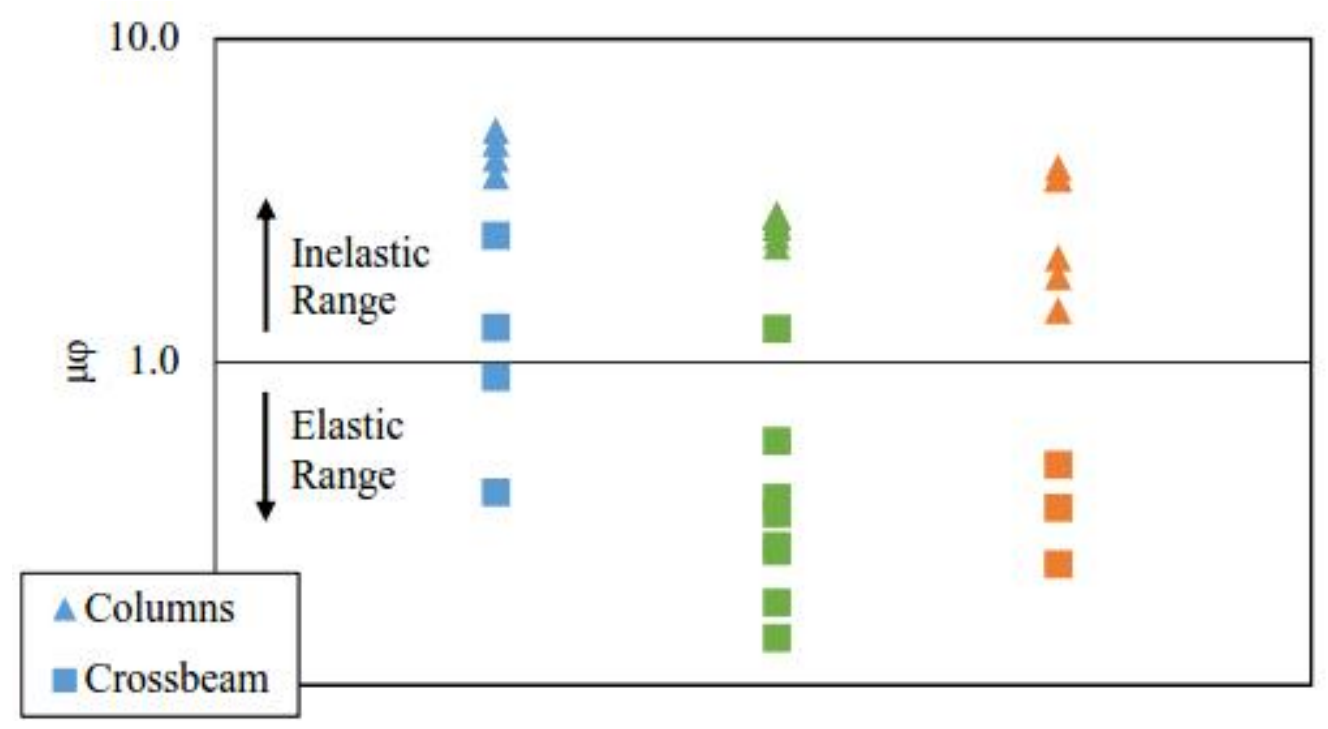

Figure 11. Existing hinge curvature ductility demands at LL ground motion 


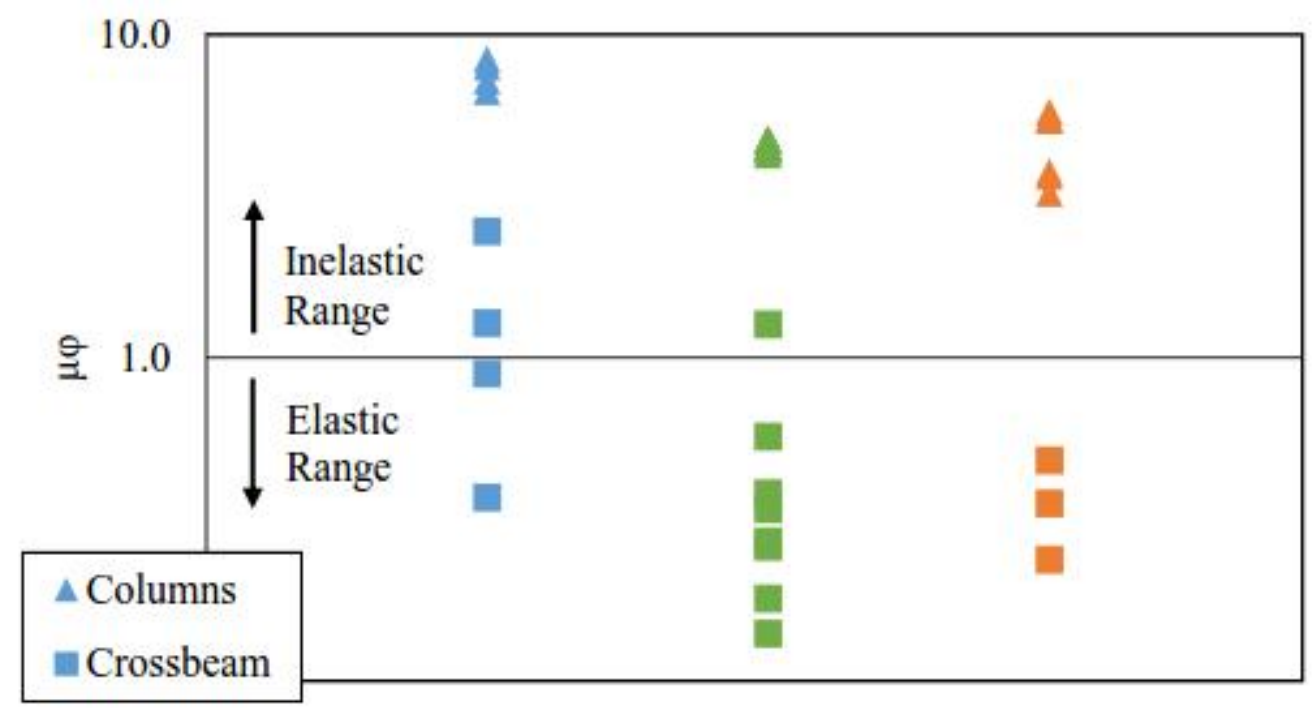

Figure 12. Existing hinge curvature ductility demands at UL ground motion

The majority of the plastic hinges form in the columns despite the detailing issues observed in the crossbeams. The crossbeams do form plastic hinges in some cases. However, the capacity of the bents was controlled by the columns. Comparing the LL results to the UL, the curvature ductility demands in the crossbeams remain the same. This shows that as the bent displacement demands increased, the column hinges continued to deflect, but the crossbeam hinges did not.

Two different approaches to meeting the operational performance criteria were considered and compared: traditional retrofit measures and buckling restrained braces. 


\subsection{TRADITIONAL RETROFIT}

ODOT's seismic retrofit program uses a two-phase approach:

- Phase 1 is intended to prevent superstructure pull-off and focuses on bearing replacements and restrainers to achieve life-safety performance criteria.

- Phase 2 involves substructure strengthening and ductility enhancement to achieve operational performance criteria.

Phase 1 retrofits in this case study were limited to shear blocks for transverse restraint in the two bridges with drop pier caps. Additional longitudinal restrainers were considered unnecessary, since abutment contributions reduce out-of-plane forces to the piers and the piers are much more flexible in this direction due to columns bending in single curvature. The orange bridge did not require any Phase 1 retrofitting due to concrete girders framing directly into the integral pier cap. The remainder of this case study focuses on Phase 2 retrofits.

Preliminary design of traditional retrofits was conducted using the Seismic Retrofitting Manual (FHWA, 2006). The seismic retrofit strategy for meeting the operational criteria is stiffening of the bent to reduce displacement demands to less than the yield displacement. It should be noted that this is in contrast to typical approaches used for retrofits aiming to achieve life-safety performance criteria, where increasing displacement capacity and ductility is the primary goal. For this reason, retrofit strategies that increase the ductility of the bent without increasing strength and stiffness, such as wrapping columns with fiber-reinforced polymer (FRP), were excluded.

The design process can be iterative, since increasing the stiffness of the structure not only reduces the elastic displacement but also decreases the fundamental period and increases the displacement magnification factors discussed previously. The following retrofit measures for bent strengthening and stiffening were considered:

- Composite full-height concrete column overlays

- Composite full-height steel column jacketing

- Full-height reinforced concrete infill walls 


\subsection{Column Concrete Overlay}

The first approach, column concrete overlay, involved strengthening the column with reinforced concrete. The overlay concrete thickness allows additional longitudinal reinforcement to be placed in the thickened section. The additional longitudinal reinforcement is doweled into the existing footings and crossbeams to provide development and enhance composite behavior. Transverse reinforcement is provided in the form of spirals or hoops to enhance shear strength and confinement of concrete. The existing concrete column surfaces are roughened to enhance interface shear transfer necessary for composite behavior. In order to provide adequate cover of the reinforcement and achieve consolidation of concrete, a minimum overlay thickness of 6" was assumed.

Subsequently, the crossbeams and footings required retrofits to be capacity-protected due to the increased strength of the columns. This forces plastic hinges to be limited to the columns. The general design procedure for this strategy was to replace the existing columns in the analysis models with retrofitted composite sections. The elastic dynamic (demand) and pushover (capacity) analyses were conducted as before. If the LL displacement demand exceeded the yield displacement demand, the design was revised. This iterative process was repeated until operational criteria were met.

Once the column retrofit design was complete, the plastic moment capacities of the retrofitted columns were multiplied by overstrength factors to determine demands for designing the crossbeam and footing retrofits. This process followed the capacity-protection principals outlined by the Seismic Retrofitting Manual (FHWA, 2006). Crossbeam strengthening generally consisted of reinforced concrete bolsters added to the sides, with drilled and bonded reinforcement through the existing crossbeams to provide composite behavior. Footing retrofits consisted of footing extensions and additional piles for stability with concrete overlays for shear and flexural strengthening.

An example of a typical bent retrofitted with column concrete overlay, crossbeam strengthening and footing strengthening is provided in Figure 13. The retrofit for the orange bridge was chosen 
to illustrate that only half of the bent was retrofitted. This was done in an attempt to minimize cost and provide the least amount of retrofit required to meet the operational performance criteria.

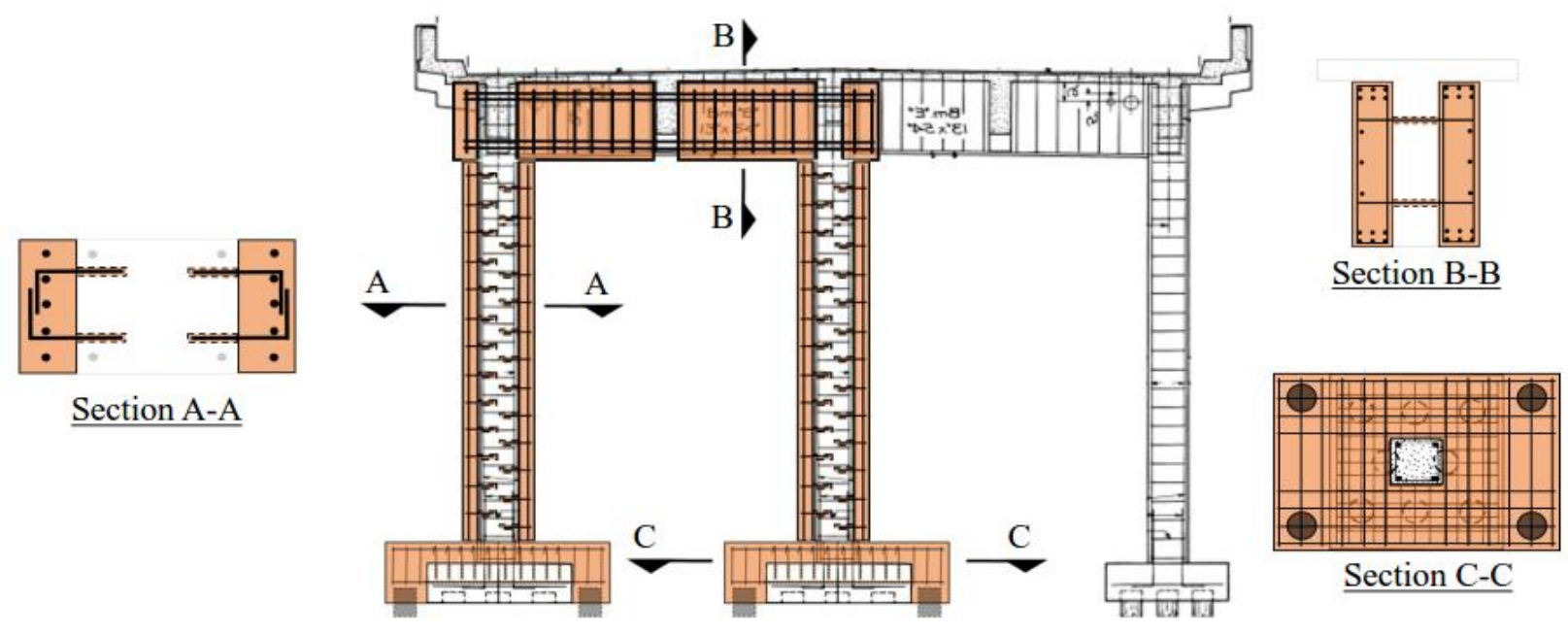

Figure 13. Orange bridge example column concrete overlay retrofit design

Rather than providing six different force-displacement curves for every retrofit design, the results were provided in tabular format. The performance criteria assessments were presented in the form of demand-to-capacity (D/C) ratios. For the operational performance criteria, the LL ground motion displacement demands, $\Delta \mathrm{D}_{\mathrm{LL}}$, were divided by the bent yield displacement, $\Delta \mathrm{y}$. Similarly, for the life-safety performance criteria, the UL ground motion displacement demands, $\Delta \mathrm{D}_{\mathrm{UL}}$, were divided by the bent displacement capacity, $\Delta \mathrm{C}$. Ratios less than 1.0 indicate that performance criteria were met. Results are presented in Table 4.

Table 4. Summary of performance criteria for column concrete overlay retrofits

\begin{tabular}{|c|c|c|c|c|c|c|c|}
\hline \multirow{2}{*}{ Bridge } & Direction & $\begin{array}{c}\Delta \mathbf{D}_{\mathbf{L L}} \\
\text { (in) }\end{array}$ & $\begin{array}{c}\mathbf{\Delta y} \\
\text { (in) }\end{array}$ & $\mathbf{D} / \mathbf{C}$ & $\begin{array}{c}\Delta \mathbf{D}_{\mathbf{U L}} \\
\text { (in) }\end{array}$ & $\begin{array}{c}\Delta \mathbf{C} \\
\text { (in) }\end{array}$ & $\mathbf{D} / \mathbf{C}$ \\
\hline \multirow{2}{*}{ Blue } & Trans. & 0.92 & 1.31 & $\mathbf{0 . 7 0}$ & 1.40 & 5.79 & $\mathbf{0 . 2 4}$ \\
\cline { 2 - 8 } & Long. & 0.67 & 2.22 & $\mathbf{0 . 3 0}$ & 1.01 & 7.43 & $\mathbf{0 . 1 4}$ \\
\hline \multirow{2}{*}{ Green } & Trans. & 1.03 & 1.28 & $\mathbf{0 . 8 0}$ & 2.16 & 6.47 & $\mathbf{0 . 3 3}$ \\
\cline { 2 - 8 } & Long. & 1.95 & 2.53 & $\mathbf{0 . 7 7}$ & 4.25 & 10.10 & $\mathbf{0 . 4 2}$ \\
\hline \multirow{2}{*}{ Orange } & Trans. & 2.08 & 2.73 & $\mathbf{0 . 7 6}$ & 2.72 & 7.04 & $\mathbf{0 . 3 9}$ \\
\cline { 2 - 8 } & Long. & 0.60 & 4.21 & $\mathbf{0 . 1 4}$ & 0.75 & 13.30 & $\mathbf{0 . 0 6}$ \\
\hline
\end{tabular}

Another important aspect of a retrofit design aimed at strengthening and stiffening is its impact to the magnitude and distribution of force demands. The base shear demands in each direction were 
also provided in tabular format along with the percentage of increase from the existing bridge. A zero percent increase $(0 \%)$ indicates the base shear demands of the retrofitted bent were the same as the existing. Negative percentages indicate a decrease in base shear relative to the existing bridge. The base shear results for the bents retrofitted with the column concrete overlays are provided in Table 5.

Table 5. Base shear demands for column concrete overlay retrofits

\begin{tabular}{|c|c|c|c|c|c|c|c|}
\hline \multirow[b]{2}{*}{ Bridge } & \multirow[b]{2}{*}{ Direction } & \multicolumn{3}{|c|}{ Lower-level Base Shear, $V_{L L}$} & \multicolumn{3}{|c|}{ Upper-level Base Shear, $V_{U L}$} \\
\hline & & $\begin{array}{c}\text { Existing } \\
\text { (kips) }\end{array}$ & $\begin{array}{c}\text { Retrofit } \\
\text { (kips) }\end{array}$ & $\begin{array}{c}\text { Increase } \\
(\%)\end{array}$ & $\begin{array}{c}\text { Existing } \\
\text { (kips) }\end{array}$ & $\begin{array}{c}\text { Retrofit } \\
\text { (kips) }\end{array}$ & $\begin{array}{c}\text { Increase } \\
(\%)\end{array}$ \\
\hline \multirow{2}{*}{ Blue } & Trans. & 222 & 432 & $95 \%$ & 216 & 583 & $170 \%$ \\
\hline & Long. & 53 & 71 & $34 \%$ & 88 & 107 & $22 \%$ \\
\hline \multirow{2}{*}{ Green } & Trans. & 291 & 409 & $41 \%$ & 291 & 506 & $74 \%$ \\
\hline & Long. & 92 & 122 & $33 \%$ & 122 & 204 & $67 \%$ \\
\hline \multirow{2}{*}{ Orange } & Trans. & 92 & 237 & $158 \%$ & 92 & 253 & $175 \%$ \\
\hline & Long. & 10 & 12 & $20 \%$ & 15 & 15 & $0 \%$ \\
\hline
\end{tabular}

Overall, the base shear demands in the longitudinal direction increased less than in the transverse direction. This was especially true for the orange bridge. One thing to note about the orange bridge is that the columns were square, as opposed to the blue and green bridges which had circular columns. The concrete overlay was applied to two of the four sides of each column, providing more stiffness and strength for transverse displacements than longitudinal. For circular columns, the concrete overlay is applied equally around the entire column and increases stiffness in all directions.

Construction costs are an important consideration when comparing bridge retrofit strategies. Preliminary construction cost estimates were prepared for each retrofit. Quantities of materials were estimated based on the preliminary retrofit designs. These quantities were then multiplied by estimated unit prices to determine total construction cost estimates of in-place materials. Preliminary construction cost estimates of the column concrete overlay retrofits for all three bridges are provided in Table 6. 
Table 6. Preliminary construction cost estimates for column concrete overlay retrofits

\begin{tabular}{|c|c|c|c|c|c|c|c|c|}
\hline \multicolumn{3}{|c|}{ Column Concrete Overlay Retrofit } & \multicolumn{2}{|c|}{ Blue bridge } & \multicolumn{2}{|c|}{ Green bridge } & \multicolumn{2}{|c|}{ Orange bridge } \\
\hline Item Description & Units & Unit Cost & Quantity & Total Cost & Quantity & Total Cost & Quantity & Total Cost \\
\hline Roughen Concrete Surface & SQFT & S $\quad 5.00$ & 1398 & $\$ 6,990$ & 1279 & $\$ 6,395$ & 890 & \$ 4,450 \\
\hline Concrete Impact Drilling $4^{\prime \prime}$ & EA & 17.00 & 332 & $\$ \quad 5,644$ & 290 & 4,930 & 568 & \$ 9,656 \\
\hline Concrete Impact Drilling Add'l & EA & 3.68 & 7240 & $\$ 26,643$ & 5280 & $\$ 19,430$ & 5544 & $\$ 20,402$ \\
\hline Reinforcement, Uncoated & LBS & 1.75 & 22451 & $\$ 39,289$ & 11047 & \$ 19,333 & 9131 & $\$ 15,979$ \\
\hline Structural Concrete, Class 4000 & CUYD & $\$ 700.00$ & 71 & $\$ 50,011$ & 43 & $\$ 30,411$ & 36 & 25,200 \\
\hline Furnish and Drive Steel Piling & EA & $\$ 1,165.00$ & 16 & $\$ 18,640$ & 16 & \$ 18,640 & 16 & $\$ 18,640$ \\
\hline TOTAL & & & & \$ 147,217 & & S 99,139 & & \$ 94,327 \\
\hline
\end{tabular}

Multiple resources were utilized in determining unit prices for the retrofit construction items. ODOT produces Bridge Cost Data $(2014,2015)$ annually based on construction bids from the previous year. This data provides current and geographically relevant cost data for many of the standard bid items and was used as much as possible. For items not included, or requiring more discretized itemization, unit prices were based on the Heavy Construction Cost Data (RS Means, 2015).

\subsection{Column Steel Jacket}

The second traditional retrofit method considered was column steel jacketing. Similar to the column concrete overlay design, the column strength and stiffness is enhanced. This time the additional strength is provided by wrapping thin-walled steel shells around the existing columns. The shell is slightly oversized, leaving a gap between the existing concrete column and the inside of the steel shell. The void is filled with high-strength grout to provide composite behavior and confinement of existing concrete. Roughening the existing concrete column surfaces and anchoring the ends of the shells to the tops of the footings and the bottom of the crossbeams enhances the likelihood of achieving composite behavior.

Again, crossbeams and footings required considerable retrofits to accommodate the increased overstrength moments from the retrofitted columns. The crossbeam and footing retrofits were very similar in approach and scale to those from the column concrete overlay retrofits. A summary of the performance criteria assessment for the column steel jacket retrofits are provided in Table 7. 
Table 7. Summary of performance criteria for column steel jacket retrofits

\begin{tabular}{|c|c|c|c|c|c|c|c|}
\hline \multirow{2}{*}{ Bridge } & Direction & $\begin{array}{c}\mathbf{A D}_{\mathbf{L L}} \\
\text { (in) }\end{array}$ & $\begin{array}{c}\mathbf{A y} \\
\text { (in) }\end{array}$ & $\mathbf{D} / \mathbf{C}$ & $\begin{array}{c}\mathbf{\Delta} \mathbf{D}_{\mathbf{U L}} \\
\text { (in) }\end{array}$ & $\begin{array}{c}\mathbf{A C} \\
\text { (in) }\end{array}$ & $\mathbf{D} / \mathbf{C}$ \\
\hline \multirow{2}{*}{ Blue } & Trans. & 0.61 & 1.18 & $\mathbf{0 . 5 2}$ & 0.93 & 2.41 & $\mathbf{0 . 3 9}$ \\
\cline { 2 - 8 } & Long. & 0.60 & 1.95 & $\mathbf{0 . 3 1}$ & 0.90 & 4.83 & $\mathbf{0 . 1 9}$ \\
\hline \multirow{2}{*}{ Green } & Trans. & 0.81 & 1.42 & $\mathbf{0 . 5 7}$ & 2.15 & 3.81 & $\mathbf{0 . 5 6}$ \\
\cline { 2 - 8 } & Long. & 1.64 & 2.70 & $\mathbf{0 . 6 1}$ & 3.67 & 6.64 & $\mathbf{0 . 5 5}$ \\
\hline \multirow{2}{*}{ Orange } & Trans. & 1.84 & 2.94 & $\mathbf{0 . 6 3}$ & 2.40 & 4.62 & $\mathbf{0 . 5 2}$ \\
\cline { 2 - 8 } & Long. & 0.51 & 3.25 & $\mathbf{0 . 1 6}$ & 0.65 & 6.67 & $\mathbf{0 . 1 0}$ \\
\hline
\end{tabular}

Similar to the column concrete overlay, base shear demands increased in both directions for every bridge. Particularly in the orange bridge, where the steel jacket increased the column stiffness considerably. While the concrete overlay was able to be applied to two sides of the square columns, the steel jacket retrofit is instead wrapped around the entire column, with the large void between the circular jacket and the square column filled with grout. A summary of the base shear demands with the steel jacket retrofits and the increase from existing bridge are provided in Table 8 .

Table 8. Base shear demands for column steel jacket retrofits

\begin{tabular}{|c|c|c|c|c|c|c|c|}
\hline \multirow{2}{*}{ Bridge } & \multirow{2}{*}{ Direction } & \multicolumn{2}{|c|}{ Lower-level Base Shear, $\mathbf{V}_{\mathbf{L L}}$} & \multicolumn{3}{|c|}{ Upper-level Base Shear, $\mathbf{V}_{\text {UL }}$} \\
\cline { 3 - 8 } & $\begin{array}{c}\text { Existing } \\
\text { (kips) }\end{array}$ & $\begin{array}{c}\text { Retrofit } \\
\text { (kips) }\end{array}$ & $\begin{array}{c}\text { Increase } \\
\text { (\%) }\end{array}$ & $\begin{array}{c}\text { Existing } \\
\text { (kips) }\end{array}$ & $\begin{array}{c}\text { Retrofit } \\
\text { (kips) }\end{array}$ & $\begin{array}{c}\text { Increase } \\
\text { (\%) }\end{array}$ \\
\hline \multirow{2}{*}{ Blue } & Trans. & 222 & 423 & $\mathbf{9 1 \%}$ & 216 & 640 & $\mathbf{1 9 6 \%}$ \\
\cline { 2 - 8 } & Long. & 53 & 103 & $\mathbf{9 4 \%}$ & 88 & 156 & $\mathbf{7 7 \%}$ \\
\hline \multirow{2}{*}{ Green } & Trans. & 291 & 471 & $\mathbf{6 2 \%}$ & 291 & 822 & $\mathbf{1 8 2} \%$ \\
\cline { 2 - 8 } & Long. & 92 & 155 & $\mathbf{6 8 \%}$ & 122 & 306 & $\mathbf{1 5 1 \%}$ \\
\hline \multirow{2}{*}{ Orange } & Trans. & 92 & 293 & $\mathbf{2 1 8 \%}$ & 92 & 361 & $\mathbf{2 9 2 \%}$ \\
\cline { 2 - 8 } & Long. & 10 & 37 & $\mathbf{2 7 0} \%$ & 15 & 47 & $\mathbf{2 1 3 \%}$ \\
\hline
\end{tabular}

Construction cost estimates for the steel jacket retrofit were considerably higher than the column concrete overlay. The unusual shape of the steel jacket shells may be a challenge to fabricate, and there is a relatively small number of shells per bridge retrofit required. The handling and fieldwelding of the shells in-place also add to the conservative unit price used for the structural steel bid item. A summary of the preliminary construction cost estimates for the steel jacket retrofits are provided in Table 9. 
Table 9. Preliminary construction cost estimates for column steel jacket retrofits

\begin{tabular}{|c|c|c|c|c|c|c|c|c|}
\hline \multicolumn{3}{|c|}{ Column Steel Jacket Retrofit } & \multicolumn{2}{|c|}{ Blue bridge } & \multicolumn{2}{|c|}{ Green bridge } & \multicolumn{2}{|c|}{ Orange bridge } \\
\hline Item Description & \begin{tabular}{|l|} 
Units \\
\end{tabular} & Unit Cost & Quantity & Total Cost & Quantity & Total Cost & Quantity & Total Cost \\
\hline Roughen Concrete Surface & SQFT & $\$ \quad 5.00$ & 1398 & $\$ 6,990$ & 1279 & $\$ \quad 6,395$ & 1231 & $\$ 6,155$ \\
\hline Concrete Impact Drilling 4" & EA & 17.00 & 320 & $\$ \quad 5,440$ & 282 & $\$ \quad 4,794$ & 400 & $\$ 6,800$ \\
\hline Concrete Impact Drilling Add'l & EA & 3.68 & 6728 & $\$ 24,759$ & 5344 & $\$ 19,666$ & 5904 & \$ 21,727 \\
\hline $\begin{array}{l}\text { Structural Steel } \\
\end{array}$ & LBS & 5.71 & 12345 & $\$ 70,490$ & 13511 & $\$ 77,148$ & 14143 & $\$ 80,757$ \\
\hline Concrete Pressure Grouting & CUFT & 165.00 & 56 & $\$ 9,240$ & 62 & $\$ 10,230$ & 262 & $\$ 43,230$ \\
\hline Reinforcement, Uncoated & LBS & 1.75 & 18349 & $\$ 32,111$ & 10364 & $\$ 18,136$ & 7877 & $\$ 13,784$ \\
\hline Structural Concrete, Class 4000 & CUYD & 700.00 & 62 & $\$ 43,711$ & 33 & $\$ 23,411$ & 32 & $\$ 22,400$ \\
\hline Furnish and Drive Steel Piling & EA & $\$ 1,165.00$ & 16 & $\$ 18,640$ & 16 & $\$ 18,640$ & 16 & $\$ 18,640$ \\
\hline $\begin{array}{l}\text { TOTAL } \\
\end{array}$ & & & & $\$ 211,381$ & & $\$ 178,420$ & & $\$ 213,493$ \\
\hline
\end{tabular}

\subsection{Concrete Infill Wall}

The third traditional retrofit method consisted of placing reinforced concrete walls between the columns from the top of the footings to the bottom of the crossbeams. This approach was modeled using elastic plate elements connected to the existing column and crossbeam nodes and fixed at the ground level. Unlike the first two traditional retrofit strategies, the concrete infill wall is controlled by shear capacity, not displacement demands. Therefore, the wall was designed for shear strength using the UL elastic demand. By designing the wall thickness and reinforcing for the UL demands, the design will be sufficient for LL demands as well.

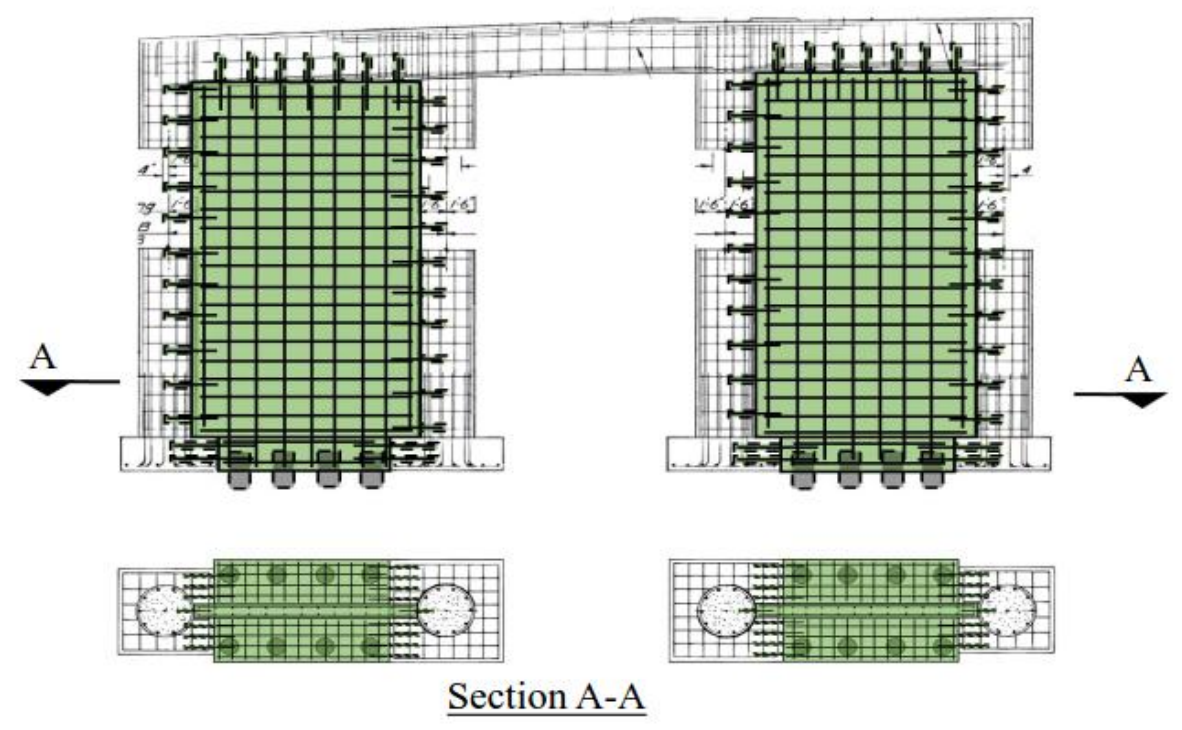

Figure 14. Green bridge example concrete infill wall retrofit design 
The interface between the bottom of the crossbeams and the top of walls was designed for shear transfer, requiring a sufficient number of drilled and bonded dowels to be provided. The reinforced concrete footing infills were checked for base shear capacity as a spread footing and piles were added to provide additional lateral resistance as necessary. A typical retrofit design using infill walls and footings is shown in Figure 14. Due to the very large shear demands exhibited by the green bridge, infill walls were designed using two bays of the four-column bents instead of just one.

Performance criteria assessment of the infill wall retrofits were based on shear demands and capacities, instead of displacements. The results of the assessment are provided in Table 10.

Table 10. Summary of performance criteria for concrete infill wall retrofits

\begin{tabular}{|c|c|c|c|c|c|c|c|}
\hline \multirow{2}{*}{ Bridge } & Direction & $\begin{array}{c}\mathbf{V}_{\text {LL }} \\
\text { (kips) }\end{array}$ & $\begin{array}{c}\text { Vr } \\
\text { (kips) }\end{array}$ & $\mathbf{D} / \mathbf{C}$ & $\begin{array}{c}\mathbf{V}_{\mathbf{U L}} \\
\text { (kips) }\end{array}$ & $\begin{array}{c}\mathbf{V r} \\
\text { (kips) }\end{array}$ & $\mathbf{D} / \mathbf{C}$ \\
\hline \multirow{2}{*}{ Blue } & Trans. & 346 & 531 & $\mathbf{0 . 6 5}$ & 525 & 531 & $\mathbf{0 . 9 9}$ \\
\cline { 2 - 8 } & Long. & 51 & 157 & $\mathbf{0 . 3 2}$ & 77 & 157 & $\mathbf{0 . 4 9}$ \\
\hline \multirow{2}{*}{ Green } & Trans. & 749 & 1229 & $\mathbf{0 . 6 1}$ & 1169 & 1229 & $\mathbf{0 . 9 5}$ \\
\cline { 2 - 8 } & Long. & 84 & 356 & $\mathbf{0 . 2 4}$ & 132 & 356 & $\mathbf{0 . 3 7}$ \\
\hline \multirow{2}{*}{ Orange } & Trans. & 289 & 438 & $\mathbf{0 . 6 6}$ & 364 & 438 & $\mathbf{0 . 8 3}$ \\
\cline { 2 - 8 } & Long. & 44 & 130 & $\mathbf{0 . 3 4}$ & 56 & 130 & $\mathbf{0 . 4 3}$ \\
\hline
\end{tabular}

The infill wall retrofits are extremely stiff in the transverse direction, but don't necessarily add a lot of stiffness in the longitudinal direction. The walls are relatively thin and do not contribute much to out-of-plane bending stiffness and resistance of the bent. An overview of the base shear demands and their increases from existing bridges are provided in Table 11.

Table 11. Base shear demands for concrete infill wall retrofits

\begin{tabular}{|c|c|c|c|c|c|c|c|}
\hline \multirow[b]{2}{*}{ Bridge } & \multirow[b]{2}{*}{ Direction } & \multicolumn{3}{|c|}{ Lower-level Base Shear, $V_{\mathrm{LL}}$} & \multicolumn{3}{|c|}{ Upper-level Base Shear, $\mathbf{V}_{\mathrm{UL}}$} \\
\hline & & $\begin{array}{c}\text { Existing } \\
\text { (kips) }\end{array}$ & $\begin{array}{c}\text { Retrofit } \\
\text { (kips) }\end{array}$ & $\begin{array}{c}\text { Increase } \\
(\%)\end{array}$ & $\begin{array}{c}\text { Existing } \\
\text { (kips) }\end{array}$ & $\begin{array}{c}\text { Retrofit } \\
\text { (kips) }\end{array}$ & $\begin{array}{c}\text { Increase } \\
(\%)\end{array}$ \\
\hline \multirow{2}{*}{ Blue } & Trans. & 222 & 346 & $56 \%$ & 216 & 525 & $143 \%$ \\
\hline & Long. & 53 & 51 & $-4 \%$ & 88 & 77 & $-13 \%$ \\
\hline \multirow{2}{*}{ Green } & Trans. & 291 & 749 & $157 \%$ & 291 & 1169 & $302 \%$ \\
\hline & Long. & 92 & 84 & $-9 \%$ & 122 & 132 & $8 \%$ \\
\hline \multirow{2}{*}{ Orange } & Trans. & 92 & 289 & $214 \%$ & 92 & 364 & $296 \%$ \\
\hline & Long. & 10 & 44 & $340 \%$ & 15 & 56 & $273 \%$ \\
\hline
\end{tabular}


The preliminary construction cost estimates for the infill walls were driven by the quantities of structural concrete, reinforcing steel and piling. This retrofit required the least amount of drilled and bonded anchors of all three traditional retrofits considered. Preliminary construction cost estimates for this retrofit strategy are provided in Table 12.

Table 12. Preliminary construction cost estimates for concrete infill wall retrofits

\begin{tabular}{|c|c|c|c|c|c|c|c|c|}
\hline \multicolumn{3}{|c|}{ Concrete Infill Wall Retrofit } & \multicolumn{2}{|c|}{ Blue bridge } & \multicolumn{2}{|c|}{ Green bridge } & \multicolumn{2}{|c|}{ Orange bridge } \\
\hline Item Description & Units & Unit Cost & Quantity & Total Cost & Quantity & Total Cost & Quantity & Total Cost \\
\hline Roughen Concrete Surface & SQFT & $\$ \quad 5.00$ & 273 & $\$ \quad 1,366$ & 457 & $\$ 2,285$ & 128 & $\$ \quad 638$ \\
\hline Concrete Impact Drilling 4" & EA & 17.00 & 261 & 4,437 & 264 & 4,488 & 122 & 2,074 \\
\hline Concrete Impact Drilling Add'l & EA & 3.68 & 2760 & $\$ 10,157$ & 2112 & $\$ 7,772$ & 648 & 2,385 \\
\hline Reinforcement, Uncoated & LBS & 1.75 & 5322 & $\$ 9,314$ & 6480 & $\$ 11,340$ & 3257 & $\$ \quad 5,700$ \\
\hline Structural Concrete, Class 4000 & CUYD & $\$ 700.00$ & 40 & $\$ 28,311$ & 55 & $\$ 38,811$ & 25 & $\$ 17,500$ \\
\hline Furnish and Drive Steel Piling & EA & $\$ 1,165.00$ & 20 & $\$ 23,300$ & 32 & $\$ 37,280$ & 8 & $\$ 9,320$ \\
\hline TOTAL & & & & \$ 76,885 & & $\$ 101,976$ & & \$ 37,617 \\
\hline
\end{tabular}

All three traditional retrofit strategies were able to be designed to meet both performance criteria for all three bridges. The first two strategies, column concrete overlay and steel jacketing, were very similar in the scope of the retrofits and their performance during seismic demands. The greatest difference between these two retrofits is the construction cost, primarily related to the materials. The reinforced concrete infill walls were considerably different in the way they achieve seismic performance. Utilizing a non-ductile response mechanism, they are designed to remain elastic during the UL ground motion, which puts considerable demands on the foundation. However, they also remain the most cost efficient of the three traditional measures considered. 


\subsection{BUCKLING RESTRAINED BRACE RETROFIT}

The BRB retrofit strategy utilizes a different approach to meeting performance criteria than the three traditional retrofits. Rather than enhancing the strength of the existing members, this strategy adds a sacrificial member intended to undergo inelastic deformations. The additional stiffness provided by the brace acts to reduce LL displacement demands and achieve operational performance criteria. The ductility of the BRB allows the dissipation of seismic energy through inelastic deformations, reducing the increase in forces transmitted to the foundations. The BRB element itself was not considered when determining the yield displacement of the retrofitted bent. Therefore, the yield displacement of the existing bent (before any retrofits) was used as the target displacement demand for the preliminary BRB retrofit design.

Design of the BRB was dependent on several factors that vary between manufacturers and materials available. The approach to the BRB design process was based on information available from manufacturers (CoreBrace, 2016) and resources such as El-Bahey and Bruneau (2011). Therefore, an overview of the BRB design process for this case study is provided but not covered in detail. The approach used the following three properties of the BRB elements for each bridge:

- Initial BRB elastic stiffness necessary to achieve target bent displacement demand

- Target BRB ductility at bent displacement demand

- Yield stress and overstrength factors for the BRB steel

The target initial elastic stiffness of the BRB was determined through iteration of the elastic dynamic analysis models using elastic BRB frame elements. The elastic BRB axial demands were determined from the model. To calculate the target BRB yield deformation, a target ductility limit was first established.

Material stress and strain properties for BRB designs were based on the research of Saxey and Daniels (2014). Typical design BRB ductility was shown between 10 and 20. An average of these typical values was used to set the ultimate ductility capacity at 15 for this study. For the retrofit design, the target BRB ductility was set to half of the ultimate capacity, or 7.5. This approach provided considerable ductility in the BRB at displacement demands while providing sufficient 
reserve ductility for greater seismic hazards. The BRB deformation demand was divided by the target ductility factor of 7.5 to determine the initial target BRB yield deformation.

A BRB design yield stress of $F y=42 \mathrm{ksi}$ and overstrength factors of $\omega=1.34$ and $\beta=1.13$ were used (Saxey \& Daniels, 2014). Combining these material properties with the initial stiffness, deformation demand, and target ductility determined previously, a preliminary design of the BRB element was completed. The required length of the core sections, cross-sectional area of the core sections, and idealized bilinear plastic hinge definitions were able to be defined.

The braces were then modeled as frame elements with rotational freedom at the ends. They were added to the analysis models using the existing nodes at the centroid of the footing and columnto-crossbeam joints. Axial plastic hinge definitions were assigned to the center of the BRB frame element for the pushover analyses. The retrofitted bents were then analyzed and the BRB properties refined until operational performance criteria were met. The resulting design parameters are provided in Table 13.

Table 13. Design properties of $B R B$ retrofits

\begin{tabular}{|c|c|c|c|c|}
\hline Bridge & $\begin{array}{c}\text { Initial stiffness } \\
\text { (kip/in) }\end{array}$ & $\begin{array}{c}\text { Total length } \\
\text { (in) }\end{array}$ & $\begin{array}{c}\text { Core length } \\
\text { (in) }\end{array}$ & $\begin{array}{c}\text { Core area } \\
\text { (in }^{\mathbf{2}} \text { ) }\end{array}$ \\
\hline Blue & 2000 & 265 & 52 & 3.59 \\
\hline Green & 500 & 259 & 189 & 3.25 \\
\hline Orange & 500 & 276 & 89 & 1.53 \\
\hline
\end{tabular}

As with the traditional retrofits, transverse restraint was provided in the form of reinforced concrete shear blocks on top the crossbeams in the blue and green bridges. The same shear block design (and therefore cost) was used for all four retrofit strategies for these two bridges.

Connections for the BRBs to bridge bents can vary significantly depending on the size and force requirements of the $\mathrm{BRB}$, geometry of the existing structure and the condition of the concrete being connected to. In all three cases, additional footing retrofits were necessary to provide stability, shear strengthening and flexural strengthening of the footing supporting the BRB connection.

A typical BRB retrofit design detail is shown for the blue bridge in Figure 15. 


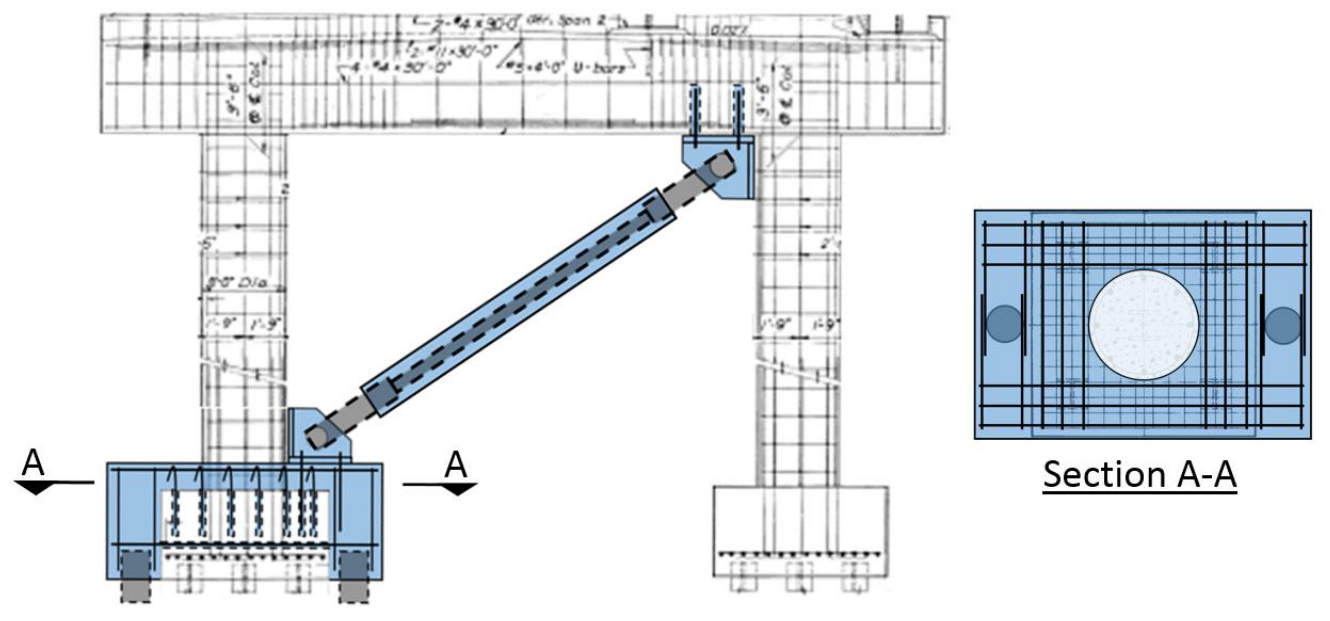

Figure 15. Blue bridge example BRB retrofit design

The BRB concentrates the majority of the lateral forces into a single footing. A large portion of the lateral force that would be resisted by the right column in Figure 15 is instead transferred through the BRB to the footing on the left. This results in considerable retrofitting of the left footing, but alleviates the need to retrofit the right footing completely. This was typical for the footings in the BRB retrofit design of all three bridges in this case study.

A summary of the performance criteria assessment of the BRB retrofitted bridges is provided in Table 14.

Table 14. Summary of performance criteria for BRB retrofits

\begin{tabular}{|c|c|c|c|c|c|c|c|}
\hline \multirow{2}{*}{ Bridge } & Direction & $\begin{array}{c}\mathbf{A D}_{\mathbf{L L}} \\
\text { (in) }\end{array}$ & $\begin{array}{c}\mathbf{A y} \\
\text { (in) }\end{array}$ & $\mathbf{D} / \mathbf{C}$ & $\begin{array}{c}\mathbf{\Delta} \mathbf{D}_{\mathbf{U L}} \\
\text { (in) }\end{array}$ & $\begin{array}{c}\mathbf{A C} \\
\text { (in) }\end{array}$ & $\mathbf{D} / \mathbf{C}$ \\
\hline \multirow{2}{*}{ Blue } & Trans. & 0.72 & 0.97 & $\mathbf{0 . 7 4}$ & 1.26 & 3.96 & $\mathbf{0 . 3 2}$ \\
\cline { 2 - 8 } & Long. & 1.02 & 1.85 & $\mathbf{0 . 5 5}$ & 1.72 & 7.75 & $\mathbf{0 . 2 2}$ \\
\hline \multirow{2}{*}{ Green } & Trans. & 1.07 & 1.31 & $\mathbf{0 . 8 2}$ & 2.30 & 5.89 & $\mathbf{0 . 3 9}$ \\
\cline { 2 - 8 } & Long. & 2.16 & 2.65 & $\mathbf{0 . 8 2}$ & 4.80 & 10.70 & $\mathbf{0 . 4 5}$ \\
\hline \multirow{2}{*}{ Orange } & Trans. & 1.68 & 2.02 & $\mathbf{0 . 8 3}$ & 2.24 & 16.38 & $\mathbf{0 . 1 4}$ \\
\cline { 2 - 8 } & Long. & 0.60 & 3.17 & $\mathbf{0 . 1 9}$ & 0.76 & 22.70 & $\mathbf{0 . 0 3}$ \\
\hline
\end{tabular}

Due to the energy dissipation that the inelastic deformation of the BRB provides, considerably less force is transmitted to the foundations than with other retrofits. Although the footings required retrofitting to accept the connection from the BRB itself, overall the foundations are protected from large increases in base shear using the BRB retrofit strategy. A summary of the base shear demands and their relative increase from the existing bridges are provided in Table 15. 
Table 15. Base shear demands for $B R B$ retrofits

\begin{tabular}{|c|c|c|c|c|c|c|c|}
\hline \multirow{2}{*}{ Bridge } & \multirow{2}{*}{ Direction } & \multicolumn{3}{|c|}{ Lower-level Base Shear, $\mathbf{V}_{\text {LL }}$} & \multicolumn{3}{|c|}{ Upper-level Base Shear, $\mathbf{V}_{\text {UL }}$} \\
\cline { 3 - 8 } & $\begin{array}{c}\text { Existing } \\
\text { (kips) }\end{array}$ & $\begin{array}{c}\text { Retrofit } \\
\text { (kips) }\end{array}$ & $\begin{array}{c}\text { Increase } \\
(\%)\end{array}$ & $\begin{array}{c}\text { Existing } \\
\text { (kips) }\end{array}$ & $\begin{array}{c}\text { Retrofit } \\
\text { (kips) }\end{array}$ & $\begin{array}{c}\text { Increase } \\
\text { (\%) }\end{array}$ \\
\hline \multirow{2}{*}{ Blue } & Trans. & 222 & 328 & $\mathbf{4 8 \%}$ & 216 & 408 & $\mathbf{8 9 \%}$ \\
\cline { 2 - 8 } & Long. & 53 & 52 & $\mathbf{- 2} \%$ & 88 & 87 & $\mathbf{- 1 \%}$ \\
\hline \multirow{2}{*}{ Green } & Trans. & 291 & 335 & $\mathbf{1 5 \%}$ & 291 & 401 & $\mathbf{3 8 \%}$ \\
\cline { 2 - 8 } & Long. & 92 & 76 & $\mathbf{- 1 7 \%}$ & 122 & 122 & $\mathbf{0} \%$ \\
\hline \multirow{2}{*}{ Orange } & Trans. & 92 & 108 & $\mathbf{1 7 \%}$ & 92 & 130 & $\mathbf{4 1 \%}$ \\
\cline { 2 - 8 } & Long. & 10 & 7.3 & $\mathbf{- 2 7 \%}$ & 15 & 9.2 & $\mathbf{- 3 9 \%}$ \\
\hline
\end{tabular}

The design and fabrication of BRB elements is very specialized and not covered by the other cost estimating references. Therefore, a preliminary cost estimate for a typical BRB element was requested from a $\mathrm{BRB}$ manufacturer. The $\mathrm{BRB}$ design parameters for the blue bridge were sent to CoreBrace LLC, who provided a preliminary cost estimate for the materials, fabrication, coating and delivery of a typical BRB element. Additional costs for the connections were estimated using the weight of structural steel plate and an estimated quantity of drilling and anchoring to existing concrete. The brace unit cost was combined with the unit cost of the two connections to determine a total unit cost per BRB installation. This typical unit cost was used for the BRB elements of all three bridges, since they were relatively similar in size.

An overview of the preliminary construction cost estimates for the BRB retrofits is provided in Table 16.

Table 16. Preliminary construction cost estimates for BRB retrofits

\begin{tabular}{|c|c|c|c|c|c|c|c|c|}
\hline \multicolumn{3}{|c|}{ BRB Retrofit } & \multicolumn{2}{|c|}{ Blue bridge } & \multicolumn{2}{|c|}{ Green bridge } & \multicolumn{2}{|c|}{ Orange bridge } \\
\hline Item Description & Units & Unit Cost & Quantity & Total Cost & Quantity & Total Cost & Quantity & Total Cost \\
\hline Buckling Restrained Brace & EA & $\$ 5,500.00$ & 2 & $\$ 11,000$ & 2 & $\$ 11,000$ & 2 & $\$ 11,000$ \\
\hline Structural Steel & LBS & $\$ \quad 5.71$ & 826 & $\$ \quad 4,715$ & 826 & $\$ \quad 4,715$ & 826 & $\$ \quad 4,715$ \\
\hline Concrete Impact Drilling 4" & EA & 17.00 & 204 & $\$ 3,468$ & 151 & 2,567 & 100 & 1,700 \\
\hline Concrete Impact Drilling Add'l & EA & 3.68 & 3144 & $\$ 11,570$ & 1808 & 6,653 & 1448 & 5,329 \\
\hline Roughen Concrete Surface & SQFT & 5.00 & 329 & $\$ 1,645$ & 265 & 1,325 & 132 & 660 \\
\hline Reinforcement, Uncoated & LBS & 1.75 & 3016 & 5,278 & 2337 & 4,089 & 705 & 1,234 \\
\hline Structural Concrete, Class 4000 & CUYD & $\$ 700.00$ & 26 & $\$ 18,511$ & 15 & $\$ 10,811$ & 13 & 9,100 \\
\hline Furnish and Drive Steel Piling & EA & $\$ 1,165.00$ & 4 & $\$ 4,660$ & 4 & $\$ 4,660$ & 4 & $\$ \quad 4,660$ \\
\hline TOTAL & & & & $\$ 60,847$ & & $\$ 45,820$ & & $\$ 38,398$ \\
\hline
\end{tabular}




\subsection{COMPARE RETROFIT STRATEGIES}

The BRB retrofit strategy for each of the three bridges was compared with the three traditional retrofit designs for each bridge. The factors considered for the comparison were the ability to meet required performance criteria, increases in base shears relative to the existing bridges, and preliminary construction cost estimates.

All four retrofit strategies were able to be designed to meet both performance criteria. However, the method by which they were able to meet them does provide some interest in their comparison. A graphical summary of the performance level D/C ratios for each of the bents is provided in Figure 16 and Figure 17. After being retrofitted to meet the operational performance criteria, all of the retrofit strategies still met the life-safety performance criteria at the UL ground motions.

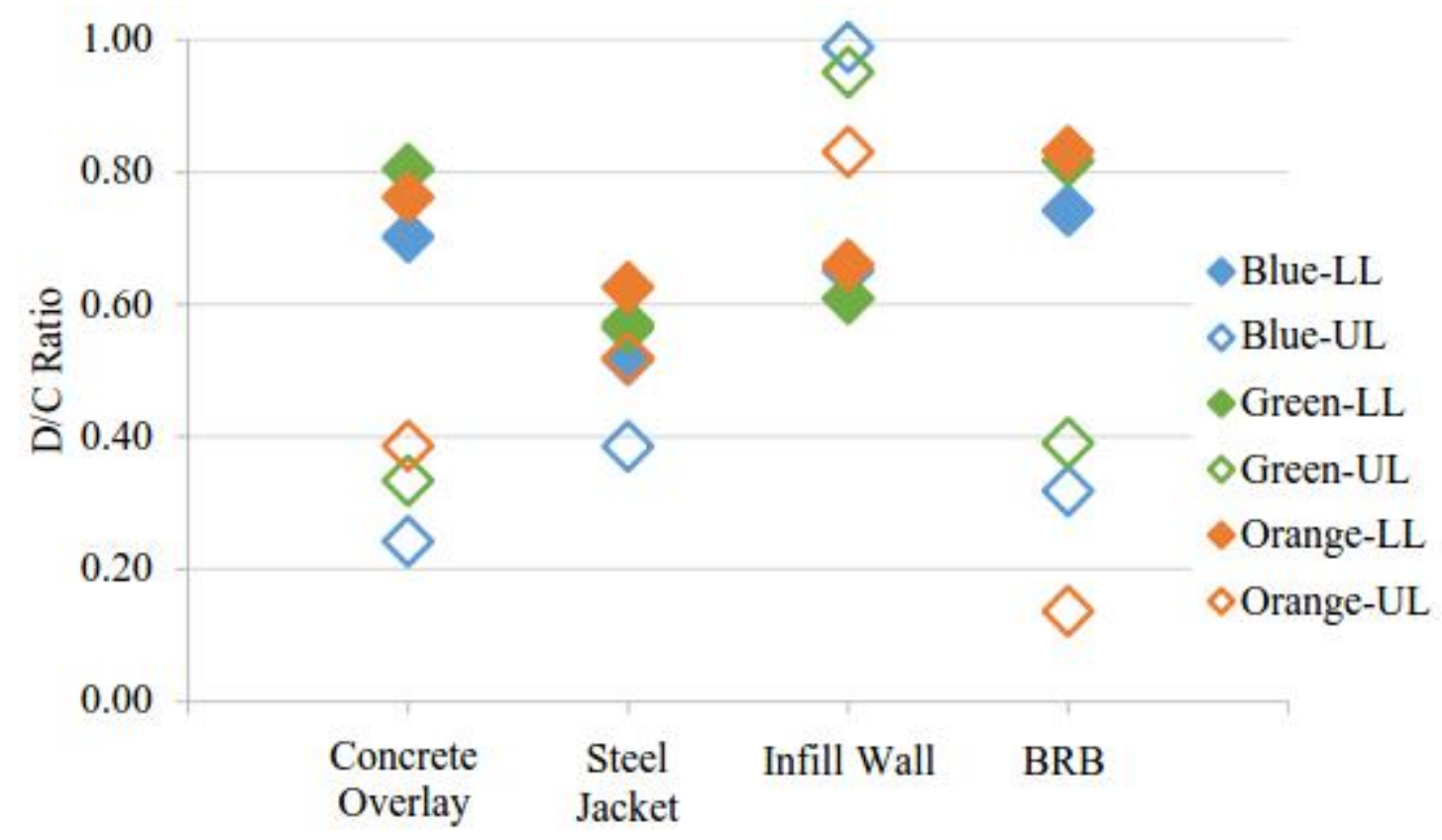

Figure 16. Comparison of performance criteria assessment for transverse demands

As discussed previously, it is worth noting that the reinforced concrete infill wall seismic performance was controlled by the upper level ground motion demands for life-safety criteria, whereas the other retrofit strategies are designed for, and controlled by, the operational criteria. 


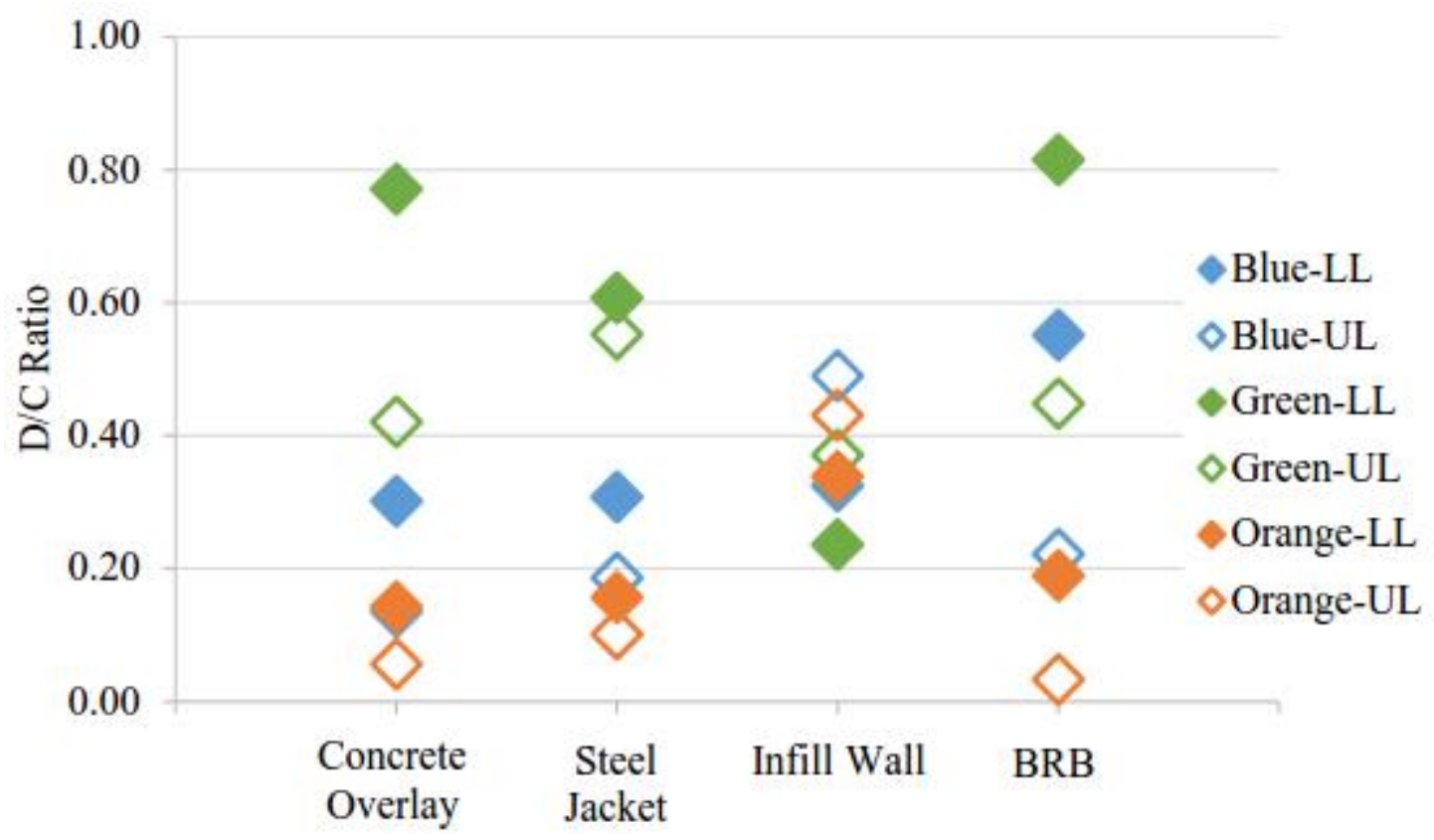

Figure 17. Comparison of performance criteria assessment for longitudinal demands

One of the apparent benefits of the BRB retrofit strategy is the ability to dissipate energy rather than transferring all of the seismic responses into the foundations. The BRB retrofits had the smallest increase in base shear demands of any retrofit strategy considered. Figure 18 shows the percentage of increase in base shear from the existing bridges for all retrofit measures in the transverse direction.

In some cases the base shear demands are even less than the existing bridge. This only happened in the longitudinal direction, but occurred in both the infill wall retrofit as well as the BRB retrofit. The longitudinal base shear increases are illustrated in Figure 19. Due to the energy dissipation provided by the BRB element, it is not as surprising that the base shear demands might be reduced using this retrofit strategy when compared to the existing bridge.

The infill wall retrofit, however, was the only traditional retrofit to have this effect. The infill wall retrofit had relatively little impact to the longitudinal stiffness of the bents while providing significant increases to the transverse stiffness. The bents retrofitted with infill walls behaved essentially elastic in all directions and therefore had displacement magnification factors of 1.0 in all cases. This resulted in a reduction in displacement demands in the longitudinal direction. 
Coupled with not having a significant increase in longitudinal bent stiffness, the result was longitudinal base shear demands less than the existing bridge.

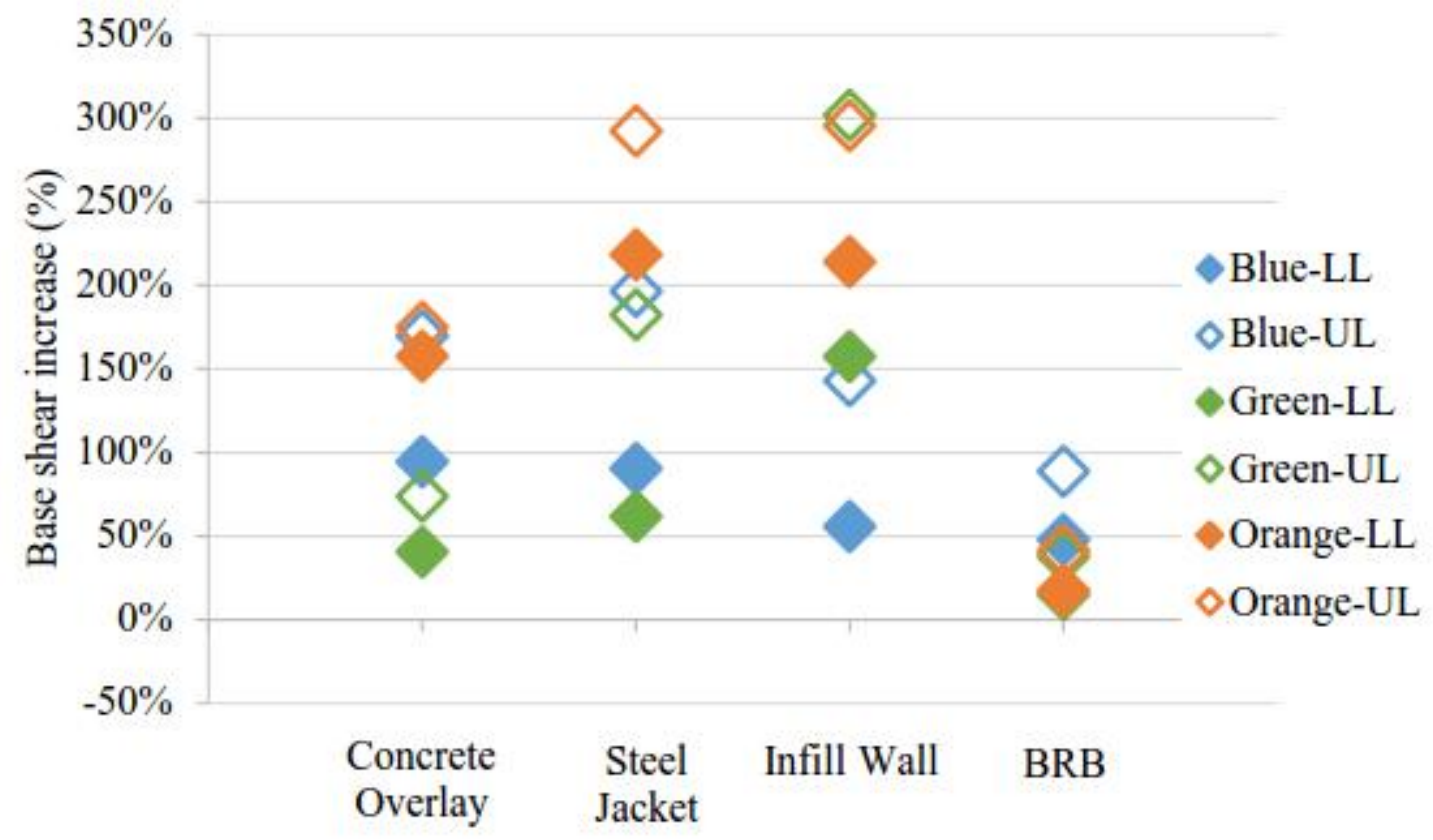

Figure 18. Percentage of transverse base shear increase from existing bridges

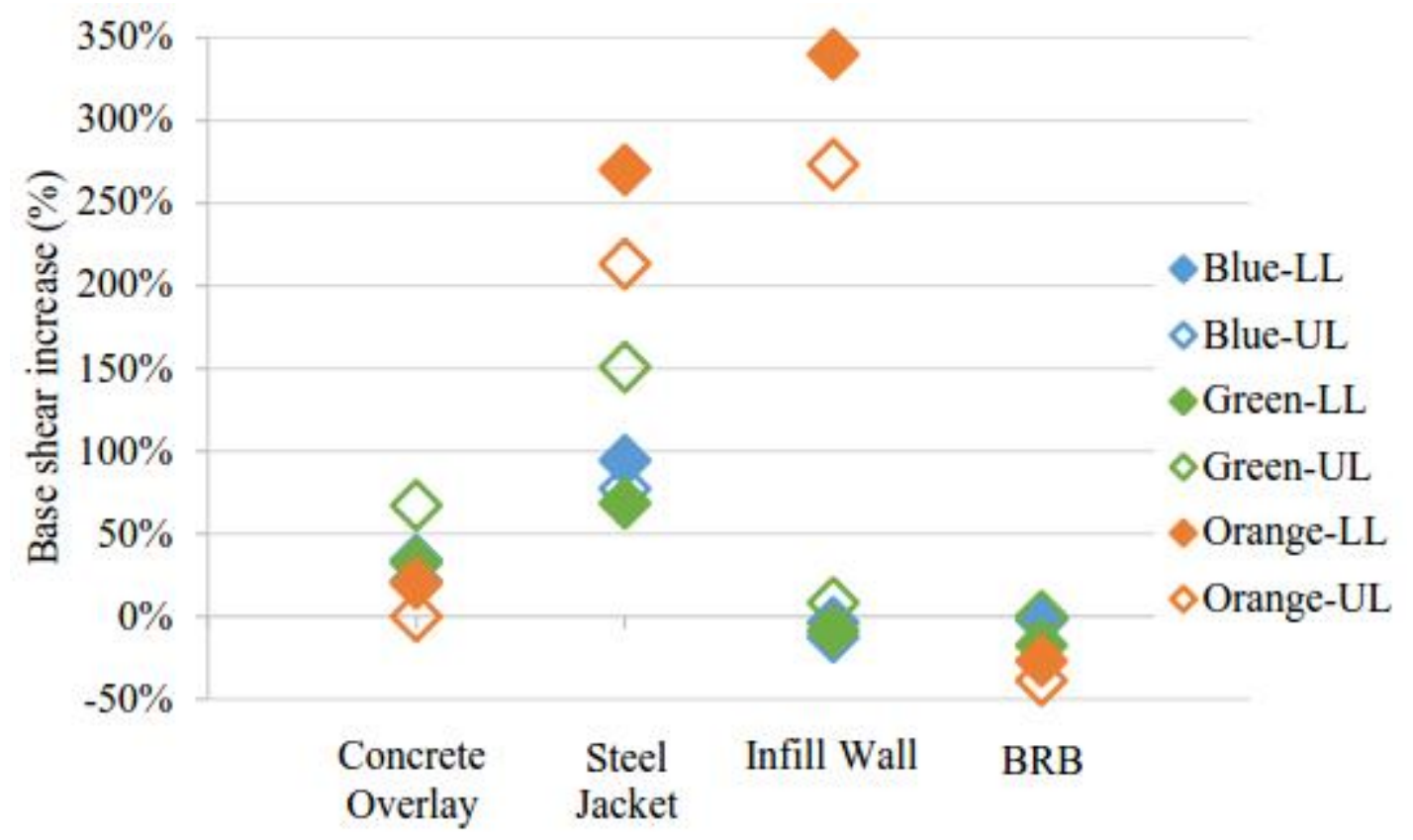

Figure 19. Percentage of longitudinal base shear increase from existing bridges

The results of the construction cost estimates for all retrofit measures considered are provided for comparison in Figure 20. The reinforced concrete infill walls are the most cost effective traditional 
retrofit strategy considered; however, the BRB retrofit was consistently the most cost effective overall.

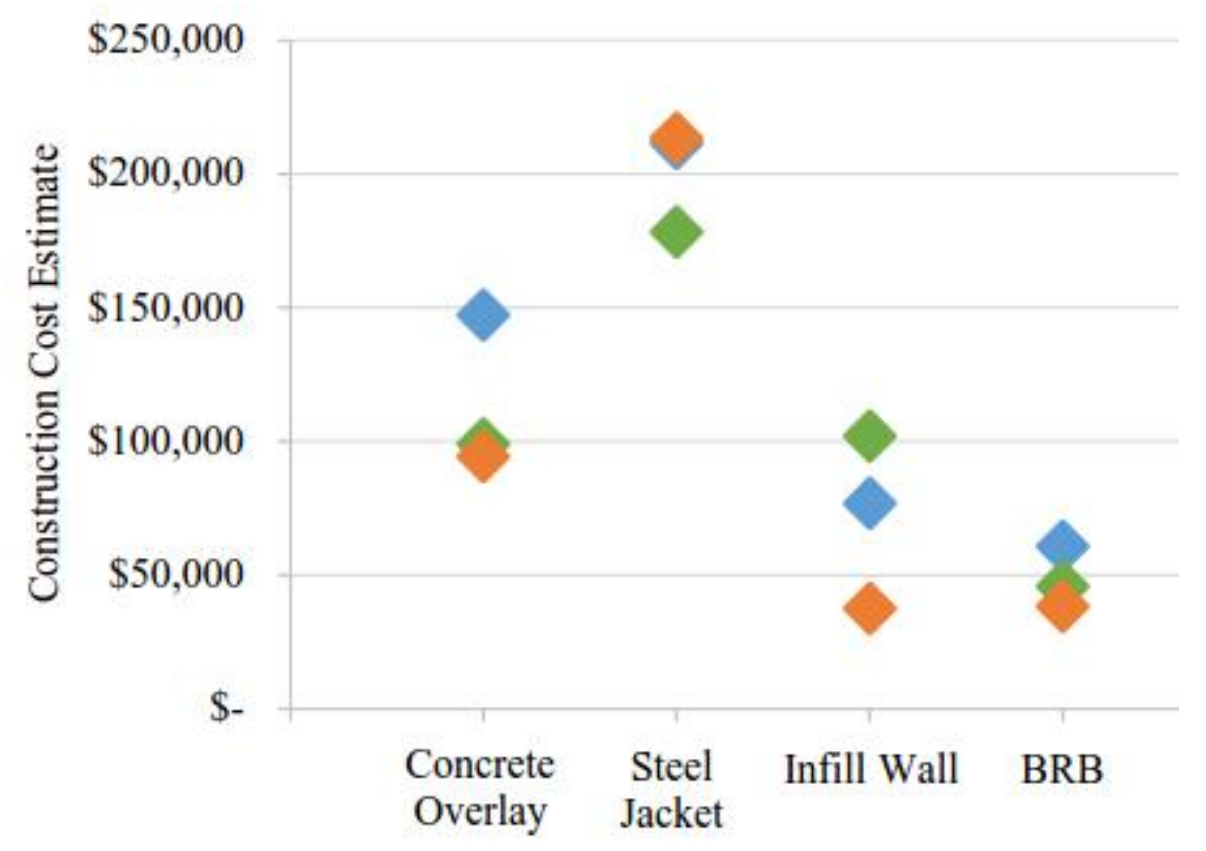

Figure 20. Comparison of total preliminary construction cost estimates for all retrofits

All four retrofit strategies were capable of meeting both performance level criteria for all three bridges. The BRB retrofit strategy provided the least increase to base shear demands in both directions of all retrofits considered for all three bridges, and even decreased base shear demands in some circumstances. The reinforced concrete infill walls and BRB retrofit strategies are both relatively cost effective; however, the BRB retrofits were more consistently the cheapest option, largely due to the small increases in forces transmitted to the foundations.

The buckling restrained brace retrofit required additional retrofitting of the existing structure in localized areas but overall protected the existing structure from damage during LL design ground motions. 


\subsection{CONCLUSIONS}

This case study explored the feasibility of buckling restrained braces as a seismic retrofit strategy for existing reinforced concrete bridges. The results of the study indicate that the BRB retrofit strategy is not only feasible but comparable to, if not better than, existing seismic retrofit strategies in both performance and cost effectiveness.

The following list summarizes the conclusions taken from this project:

- Many existing structures that meet life-safety performance criteria fail operational performance criteria.

- Full-rupture Cascade Subduction Zone Earthquake response spectra will likely increase operational performance criteria demands from the previous 500-year design event for bridges west of Interstate 5.

- Bridges with skewed supports are more likely to require seismic retrofitting for longitudinal demands.

- Except for bridges with skewed supports, seismic retrofitting is not likely to be required for longitudinal seismic demands.

- Buckling restrained brace seismic retrofits meet operational performance criteria with the least increase to base shear demands.

- Buckling restrained brace seismic retrofits are cost-competitive with existing Phase 2 seismic retrofit strategies. 


\subsection{REFERENCES}

AASHTO (American Association of State Highway and Transportation Officials). (2011). Guide Specifications for LRFD Seismic Bridge Design, $2^{\text {nd }}$ Edition, Washington, DC.

CoreBrace. (2016). “Pinned-Brace-Design-Guide.” CoreBrace, LLC, West Jordan, UT.

El-Bahey, S., and Bruneau, M. (2011). "Buckling restrained braces as structural fuses for the seismic retrofit of reinforced concrete bridge bents." Engineering. Structures, 33: 1052-1061.

FHWA (Federal Highway Administration). (2006). "Seismic Retrofitting Manual for Highway Structures: Part 1 - Bridges.” FHWA-HRT-06-032, McLean, VA.

ODOT (Oregon Department of Transportation). (2016). Bridge Design and Drafting Manual, Salem, OR.

ODOT. (2016). 2015 Bridge Cost Data, Salem, OR.

ODOT. (2015). 2014 Bridge Cost Data, Salem, OR.

Priestley, M., Seible, F., and Calvi, G. (1996). "Seismic Design and Retrofit of Bridges." John Wiley \& Sons, Inc., New York, NY.

RSMeans. (2015). Heavy Construction Cost Data, $29^{\text {th }}$ Edition, Norwell, MA.

SAP2000 v18.2.0 [computer software]. Computers and Structures, Inc., Walnut Creek, CA.

Saxey, B., and Daniels, M. (2014). "Characterization of Overstrength Factors for Buckling Restrained Braces.” ASEC Conference 2014, PN: 179.

WSDOT (Washington State Department of Transportation). (2015). Bridge Design Manual, Olympia, WA. 